\title{
Variations in surface ozone and carbon monoxide in the Kathmandu Valley and surrounding broader regions during SusKat-ABC field campaign: role of local and regional sources
}

\author{
Piyush Bhardwaj ${ }^{1,2, a}$, Manish Naja ${ }^{1}$, Maheswar Rupakheti ${ }^{3}$, Aurelia Lupascu ${ }^{3}$, Andrea Mues ${ }^{3}$, \\ Arnico Kumar Panday ${ }^{4}$, Rajesh Kumar ${ }^{5}$, Khadak Singh Mahata ${ }^{3}$, Shyam Lal ${ }^{6}$, Harish C. Chandola ${ }^{2}$, and \\ Mark G. Lawrence ${ }^{3}$ \\ ${ }^{1}$ Aryabhatta Research Institute of Observational Sciences (ARIES), Nainital, 263002, India \\ ${ }^{2}$ Department of Physics, DSB Campus, Kumaun University, Nainital 263001, India \\ ${ }^{3}$ Institute for Advanced Sustainability Studies (IASS), Potsdam, 14467, Germany \\ ${ }^{4}$ International Centre for Integrated Mountain Development (ICIMOD), Kathmandu, 44700, Nepal \\ ${ }^{5}$ National Center for Atmospheric Research (NCAR) Boulder, 80301, USA \\ ${ }^{6}$ Physical Research Laboratory (PRL), Ahmedabad, 380009, India \\ ${ }^{a}$ now at: Gwangju Institute of Science and Technology (GIST), Gwangju, 61005, Republic of Korea
}

Correspondence: Manish Naja (manish@aries.res.in)

Received: 2 April 2017 - Discussion started: 17 July 2017

Revised: 17 May 2018 - Accepted: 27 June 2018 - Published: 21 August 2018

\begin{abstract}
Air pollution resulting from rapid urbanization and associated human activities in the Kathmandu Valley of Nepal has been leading to serious public health concerns over the past 2 decades. These concerns led to a multinational field campaign SusKat-ABC (Sustainable atmosphere for the Kathmandu Valley - Atmospheric Brown Clouds) that measured different trace gases, aerosols and meteorological parameters in the Kathmandu Valley and surrounding regions during December 2012 to June 2013 to understand local- to regional-scale processes influencing air quality of the Kathmandu Valley. This study provides information about the regional distribution of ozone and some precursor gases using simultaneous in situ measurements from a SusKat-ABC supersite at Bode, Nepal, and two Indian sites: a high-altitude site, Nainital, located in the central Himalayan region and a low-altitude site, Pantnagar, located in the Indo-Gangetic Plain (IGP). The diurnal variations at Bode showed a daytime buildup in $\mathrm{O}_{3}$ while $\mathrm{CO}$ shows morning and evening peaks. Similar variations (with lower levels) were also observed at Pantnagar but not at Nainital. Several events of hourly ozone levels exceeding $80 \mathrm{ppbv}$ were also observed at Bode. The CO levels showed a decrease from their peak level of about $2000 \mathrm{ppbv}$ in January to about $680 \mathrm{ppbv}$ in June at Bode. The hourly mean ozone and $\mathrm{CO}$ levels showed a
\end{abstract}

strong negative correlation during winter $\left(r^{2}=0.82\right.$ in January and $r^{2}=0.71$ in February), but this negative correlation gradually becomes weaker, with the lowest value in May $\left(r^{2}=0.12\right)$. The background $\mathrm{O}_{3}$ and $\mathrm{CO}$ mixing ratios at Bode were estimated to be about 14 and $325 \mathrm{ppbv}$, respectively. The rate of change of ozone at Bode showed a more rapid increase $\left(\sim 17 \mathrm{ppbv} \mathrm{h}^{-1}\right)$ during morning than the decrease in the evening $\left(5-6 \mathrm{ppbv} \mathrm{h}^{-1}\right)$, suggesting the prevalence of a semi-urban environ. The lower CO levels during spring suggest that regional transport also contributes appreciably to springtime ozone enhancement in the Kathmandu Valley on top of the local in situ ozone production. We show that regional pollution resulting from agricultural crop residue burning in northwestern IGP led to simultaneous increases in $\mathrm{O}_{3}$ and $\mathrm{CO}$ levels at Bode and Nainital during the first week of May 2013. A biomass-burning-induced increase in ozone and related gases was also confirmed by a global model and balloon-borne observations over Nainital. A comparison of surface ozone variations and composition of light non-methane hydrocarbons among different sites indicated the differences in emission sources of the Kathmandu Valley and the IGP. These results highlight that it is important to consider regional sources in air quality management of the Kathmandu Valley. 


\section{Introduction}

The Himalayan region is among the least studied regions in the world despite its known importance in influencing the livelihood of about a billion people and agricultural systems. The Himalayas are spread over a large region including Afghanistan, Pakistan, India, Nepal, Bangladesh, Bhutan, China, and Myanmar and provide fresh water to about a billion people living in this region. However, the growing economies, industrialization and increasing population in the region are polluting this pristine environment and perturbing the regional environment, climate and ecosystems. The urban centers in the mountain regions often face severe air pollution problems since the mountains act as a barrier to horizontal ventilation of the pollutants and local mountain valley winds govern the diurnal variations in air pollutants. These processes have been well studied over other parts of the world, such as Mexico City (de Foy et al., 2006; Molina et al., 2007 etc.), Po Valley (Martilli et al., 2002) and Santiago de Chile (Schmitz, 2005; Rappenglück et al., 2005). The Kathmandu Valley, located in the central Himalayas, is an ideal natural laboratory to study such processes. However, only a few surface measurements of ozone and related trace species have been reported so far from this region (Pudasainee et al., 2006; Panday and Prinn, 2009; Cristofanelli et al., 2010; Putero et al., 2015; Mahata et al., 2017).

The valley has experienced an unprecedented growth as the population increased nearly 4 -fold from about 0.75 million to about 3 million over the last 25 years. The total vehicle fleet in the Bagmati Zone, where the Kathmandu Valley is situated, increased by about 22 times from about 34600 in 1989-1990 to about 755000 vehicles in 2013-2014 (DOTM, 2015). Consequently, the total fossil fuel usage in the valley is about $50 \%$ of all of Nepal. The shares of coal, petrol, diesel kerosene and liquefied petroleum gas (LPG) usage in the Kathmandu Valley range between $35 \%$ and $66 \%$ when compared with their respective usage in all of Nepal (Pradhan et al., 2012). These unprecedented growths can have serious implications for the air quality and its impacts on the Kathmandu Valley; higher occurrences of respiratory problems and skin and eye irritation have already been observed among the people living in the Kathmandu Valley than in other areas (Pradhan et al., 2012). In the past, elevated levels of $\mathrm{O}_{3}, \mathrm{CO}, \mathrm{NO}_{x}$ and volatile organic compounds (VOCs) have been reported over this region during winter and premonsoon seasons (Pudasainee et al., 2006; Panday and Prinn, 2009).

In order to advance our understanding of air quality in the Kathmandu Valley and to understand how the magnitude of and variability in air pollution in the Kathmandu Valley compares with other sites in the region, the Sustainable Atmosphere for the Kathmandu Valley - Atmospheric Brown Clouds (SusKat-ABC) international air pollution measurement campaign was carried out in Nepal during December 2012-June 2013, with an initial intensive measurement period of 2 months from December 2012 to February 2013 (Rupakheti et al., 2018). A total of 18 international research groups participated and various instruments for the extensive measurements of aerosols, trace gases and meteorological parameters were installed. The campaign covered a total of 23 sites of various measurement capabilities in the region with a supersite at Bode, five satellite sites in and on the Kathmandu Valley's rim, five regional sites (Lumbini, Pokhara, Jomsom, Dhunche and the Nepal Climate Observatory at Pyramid (NCOP) near Mt. Everest), and other collaborating sites in India and China, including Nainital and Pantnagar in India. Measurements of short-lived climate-forcing pollutants (SLCPs), i.e., ozone and black carbon, at Paknajol near the city center of Kathmandu during the SusKatABC campaign are reported in Putero et al. (2015). However, that study lacked the collocated measurements of $\mathrm{O}_{3}$ precursors. Sarkar et al. (2016) presented the measurements of non-methane volatile organic compounds (NMVOCs) at $1 \mathrm{~s}$ resolution using proton-transfer-reaction time-of-flight mass spectrometry (PTR-TOF-MS) and a study on two greenhouse gases is described by Mahata et al. (2017) at Bode during the campaign. These studies provided important information about atmospheric composition in the Kathmandu Valley during the SusKat-ABC period; however, a regional picture of the variability in ozone and related gases has not been presented so far.

In light of the above conditions, this study aims to provide the first information about the regional distribution of ozone and related gases during SusKat-ABC by synergistically analyzing simultaneous in situ measurements of surface ozone and CO at Bode from January to June 2013 with those from two Indian sites, namely Nainital (a high-altitude site in the central Himalayas) and Pantnagar (a low-altitude site in the Indo-Gangetic Plain, IGP). Additional observations at the two Indian sites are used to understand the similarities and differences between the air quality of the Kathmandu Valley and the Indian sites and identify any regional emission source common to these sites. The previous measurements of ozone in the Kathmandu Valley were only performed near the city centers; however, Bode is on the eastern side of the valley and is generally downwind of the major urban centers of the Kathmandu Valley (Kathmandu Metropolitan City and Lalitpur Sub-metropolitan City). This site also receives regional air masses from the west and south, especially during afternoons with stronger wind speeds. Therefore, this site can serve as a better representative for discerning the background levels of $\mathrm{O}_{3}$ and $\mathrm{CO}$ in the Kathmandu Valley.

\section{Experimental details}

\subsection{Observation sites}

The Kathmandu Valley is an oval-shaped urban basin located in the central Himalayan foothills between the IGP 


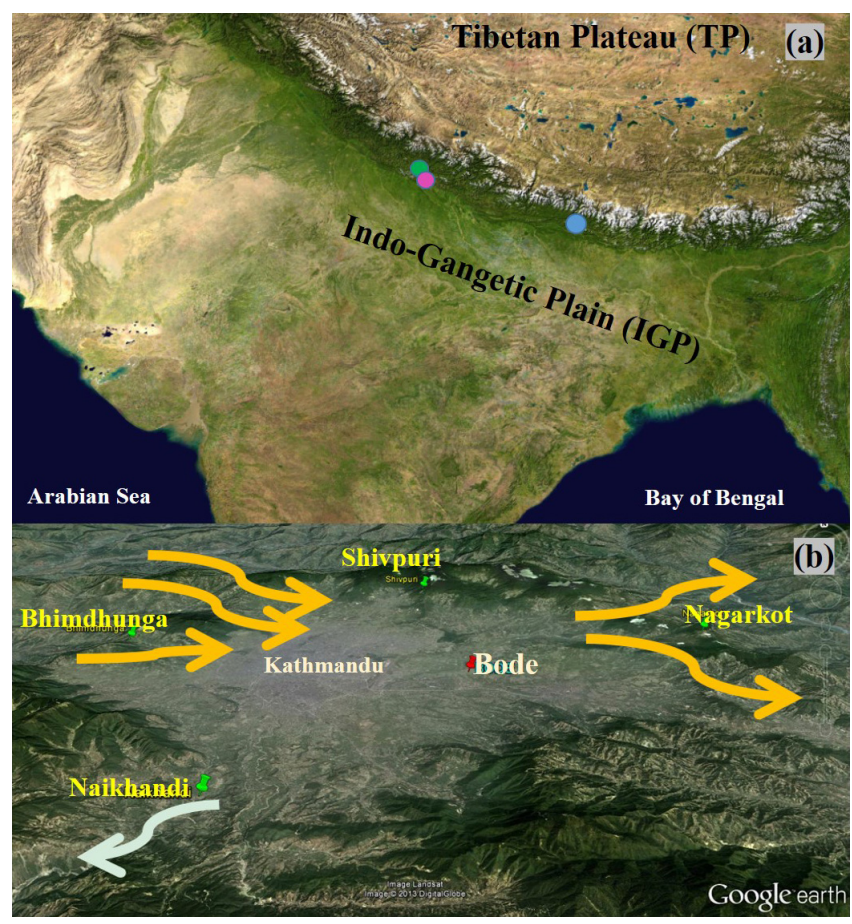

Figure 1. (a) Satellite image depicting the location of observation sites, namely, Bode (blue) in the Kathmandu Valley, Nepal, and Nainital (green) and Pantnagar (pink) in India during the SusKat field campaign. (b) Satellite image of the Kathmandu Valley (edge in view) with the super site (Bode) and four satellite sites (Bhimdhunga, Naikhandi, Nagarkot and Shivpuri). Panel (b) also indicates the position of five mountain passes surrounding the valley (yellow arrows) and one river outflow location (white).

and the Tibetan Plateau (Fig. 1). The valley is surrounded by mountain peaks with an altitude ranging from 2000 to $2800 \mathrm{~m}$ above mean sea level (a.m.s.l.) and five mountain passes (Nagdhunga, Bhimdhunga and Mudkhu Bhanjyang in the west and Sanga and Nagarkot in the east) with an altitude ranging from 1500 to $1550 \mathrm{~m}$ a.m.s.l., and the outlet of the Bagmati River is in the southwest corner of the valley. The flat base area of the Kathmandu Valley is about $340 \mathrm{~km}^{2}$ with a mean elevation of about $1300 \mathrm{~m}$ a.m.s.l. There is no river inlet into the Kathmandu Valley and only one narrow river outlet (Bagmati River) on the southwestern side. The spatial extent of the valley is about $25 \mathrm{~km}$ east-west and around $20 \mathrm{~km}$ in the north-south direction. The measurement sites located in the Kathmandu Valley during the SusKat field campaign are depicted in Fig. 1b. In this study observations of $\mathrm{O}_{3}, \mathrm{CO}$ and meteorological parameters made at Bode $\left(27.68^{\circ} \mathrm{N}, 85.39^{\circ} \mathrm{E}, 1344 \mathrm{~m}\right.$ a.m.s.l.) and at two sites in India, namely, ARIES, Nainital, a high-altitude site located on a mountaintop $\left(29.36^{\circ} \mathrm{N}, 79.45^{\circ} \mathrm{E}, 1958 \mathrm{~m}\right.$ a.m.s.l. $)$, and Pantnagar, located in the Himalayan foothills on the IGP $\left(29.0^{\circ} \mathrm{N}, 79.5^{\circ} \mathrm{E}, 231 \mathrm{~m}\right.$ a.m.s.1.), are discussed.

Two observations sites in India, i.e., Nainital and Pantnagar, represent cleaner Himalayan and polluted IGP envi- ronments, respectively. Surface ozone levels at Nainital are found to be driven mainly by transport of anthropogenic emissions from the IGP region (Kumar et al., 2010, 2011), while those at Pantnagar are mostly controlled by local emissions (Ojha et al., 2012). In the previous studies, the pollutant levels in the Kathmandu Valley were reported to be primarily influenced by the local emissions and the unique meteorology in the region (Panday et al., 2009; Putero et al., 2015).

\subsection{Ozone and CO measurements}

Surface ozone measurements are conducted using two types of analyzers, i.e., Teledyne M400E (at Bode and Pantnagar) and Thermo model 49i (at Nainital). The observation principle of both the instruments is based on the commonly used technique of attenuation of UV radiation $(\sim 254 \mathrm{~nm})$ by ozone molecules. These instruments are regularly subjected to zero and span tests using an internal ozone generator, and ozone observations from both the instruments are also intercompared by running them side by side and using a common inlet. Further details of such intercomparisons are reported in Sarangi et al. (2014).

$\mathrm{CO}$ measurements are also conducted using two types of analyzers, i.e., Horiba APMA-370 (at Bode and Pantnagar) and Thermo 48i (at Nainital). The CO instrument, at Bode, was deployed for the first time in field after factory calibration from the manufacture. Nevertheless, both CO instruments were intercompared using a common inlet prior to the campaign. The correlation coefficient among $\mathrm{CO}$ mixing ratios measured by the instruments is estimated to be $\sim 0.9$ with a slope of 1.09. CO instruments are based on the commonly used method of infrared (IR) absorption by the $\mathrm{CO}$ molecules at $4.6 \mu \mathrm{m}$. Regular zero checks and span checks for $\mathrm{CO}$ instruments are performed using a primary calibration mixture from Linde, UK (1150 ppbv; Sarangi et al., 2016) and secondary gas from Chemtron Science Laboratories (1790 ppbv). Multipoint calibrations (ultrapure gases) are also carried out in different observational ranges using a zero air generator (Thermo model 1160) and a dynamic gas calibrator (Thermo model 146i) (Sarangi et al., 2014). The meteorological measurements at Bode are performed using an automatic weather station (Campbell Scientific, UK).

Both the $\mathrm{O}_{3}$ and $\mathrm{CO}$ instruments were installed on the fourth floor of a building in Bode facing the eastern side of the Kathmandu Valley (Fig. 2; refer to Sarkar et al., 2016, for site description). The sampling inlet for these instruments was placed at the top of the building and Teflon (TFE) tubes were used for the air intake. The $\mathrm{O}_{3}$ and $\mathrm{CO}$ instruments at Nainital and Pantnagar were placed in the atmospheric science building at Manora Peak (refer to Sarangi et al., 2014, for site description) and at the College of Basic Sciences and Humanities (CBSH), G. B. Pant University of Agriculture and Technology (GBPUAT), at Pantnagar (refer to Ojha et al., 2012, for site description). Observations at Bode are in Nepalese standard time (NST), which is $05: 45 \mathrm{~h}$ ahead of 


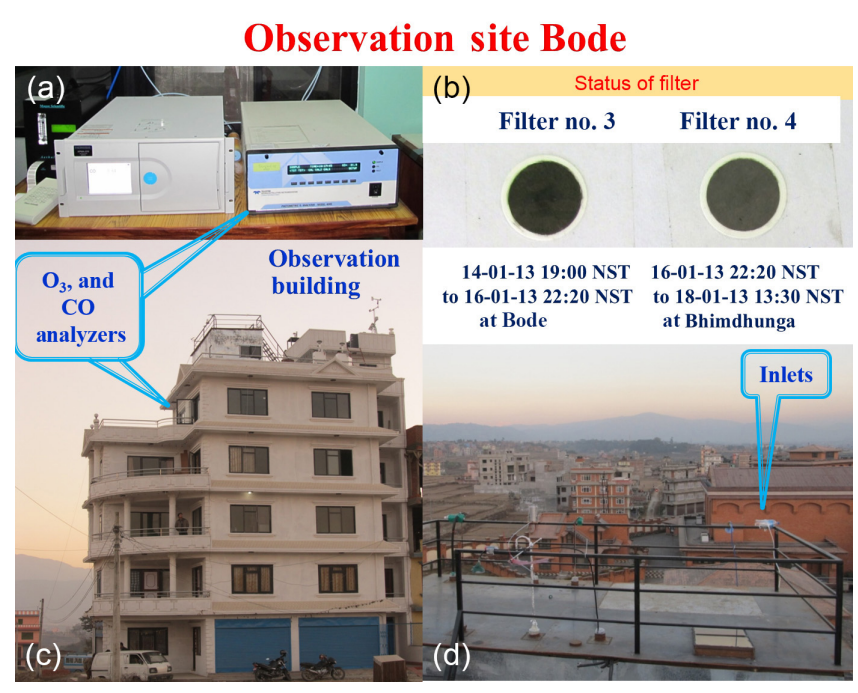

Figure 2. The observation setup with $\mathrm{O}_{3}$ and $\mathrm{CO}$ analyzers (a) placed at the fourth floor of a building at Bode, Nepal (c). The position of sampling inlets is towards the eastern side of the valley (d). Almost black inlet filters are seen for 2 days of operation at the Bode and Bhimdhunga sites (b).

GMT, and observations at Nainital and Pantnagar are in Indian standard time, which is $05: 30 \mathrm{~h}$ ahead of GMT.

\subsection{Air sampling and analysis for hydrocarbons}

A total of 16 air samples are collected at Bode from 30 December 2012 to 14 January 2013 with the frequency of one sample per day. These air samples are collected at 14:00 NST (two samples at 12:00 NST) when the boundary layer is fully evolved and the air is well mixed. Air samples are collected at a pressure of $1.5 \mathrm{bar}$ and analyzed for ethane, ethene, propane, $i$-butane, $n$-butane, acetylene and $i$-pentane using a gas chromatograph (HP 5890 II) equipped with a flame ionization detector and a PLOT column of $\mathrm{KCl} / \mathrm{Al}_{2} \mathrm{O}_{3}$. Helium is employed as the carrier gas and $\mathrm{H}_{2}$ and zero air are used for flame. Air samples are also analyzed for $\mathrm{CH}_{4}$ and $\mathrm{CO}$ using another gas chromatograph (Varian Vista, 6000, USA) and employing a molecular sieve 13 times with a packed column $(4 \mathrm{~m})$. $\mathrm{CO}$ is measured by converting in to $\mathrm{CH}_{4}$ using a $\mathrm{Ni}$ catalyst heated to about $325^{\circ} \mathrm{C}$. A standard mixture from Intergas (International Gases and Chemicals Ltd.), UK, traceable to National Physical Laboratory (NPL), UK, is employed for the calibration of non-methane hydrocarbons (NMHCs). Gases from NIST, USA, and Linde, UK, are used for the calibration of $\mathrm{CH}_{4}$ and $\mathrm{CO}$. More details on sample pre-concentration and calibration can be seen in Lal et al. (2008), Mallik et al. (2014) and Sarangi et al. (2016).

\subsection{Satellite data emissions and backward air trajectory}

In this study, the Ozone Monitoring Instrument (OMI) level 3 daily tropospheric column amount $\mathrm{NO}_{2}$ data product OMNO2d (cloud screened at $30 \%$ ) at $0.25^{\circ} \times 0.25^{\circ}$ resolution is used to generate spatial maps during biomass burning periods. This product is based on the radiance measurements made by the OMI instrument in visible (VIS, 405$465 \mathrm{~nm}$ ) channels. A detailed description of measurement principles can be found in Bucsela et al. (2013). The fire locations during the springtime biomass burning are used from monthly MODIS collection 6, level 2 (combined Aqua and Terra) global monthly fire product mcd $14 \mathrm{ml}$ at $1 \mathrm{~km}$ resolution (Giglio, 2010). For this study fire locations with high detection confidence $(>80 \%)$ are used and a detailed detection principle can be found in Giglio et al. (2003) and Justice et al. (2006). NASA's Atmospheric Infrared Sounder (AIRS) instrument suite measures atmospheric water vapor and temperature profiles on a global scale. At present the operational instruments in this suite consist of a hyperspectral infrared instrument (AIRS) and a multichannel microwave instrument, Advanced Microwave Sounding Unit-A (AMSUA). Apart from meteorological datasets, these instruments also retrieve the vertical profiles of some of the trace gases such as ozone and $\mathrm{CO}$, and a detailed description of retrieval algorithms is discussed in Susskind et al. (2003, 2006). In this study the vertical profiles of ozone, $\mathrm{CO}$ and relative humidity (RH) from the AIRS + AMSU joint data product (AIRX3STD v006) at $1^{\circ}$ spatial resolution are used to understand stratosphere-troposphere transport phenomena during January-May 2013.

The biomass burning emissions of $\mathrm{CO}$ were estimated using Global Fire Emissions Database (GFED) version 4 datasets. These data use satellite information of fire hot spots and vegetation productivity to calculate gridded fire emissions. The data also included a fractional contribution of different types of vegetation to fire emissions. The version 4 dataset has a spatial resolution of $0.25^{\circ}$, and a detailed description about the dataset and data access could be found from http://www.globalfiredata.org/data.html (last access: 15 October 2017). The Modern-Era Retrospective analysis for Research and Applications version 2 (MERRA-2) is the reanalysis dataset produced by the Global Modeling and Assimilation Office (GMAO) of NASA. In this study Ertel potential vorticity data from this reanalysis are used and more details can be found in Gelaro et al. (2017).

To understand the history of air masses arriving at Bode, the Hybrid Single-Particle Lagrangian Integrated Trajectory (HYSPLIT) model (Draxler and Hess, 1998) is used. The high-resolution $\left(0.5^{\circ} \times 0.5^{\circ}\right)$ meteorological fields from the Global Data Assimilation System (GDAS) are used to generate 5-day backward trajectories over Bode. These trajectories are initiated as an ensemble of nine points separated by $0.25^{\circ}$ 


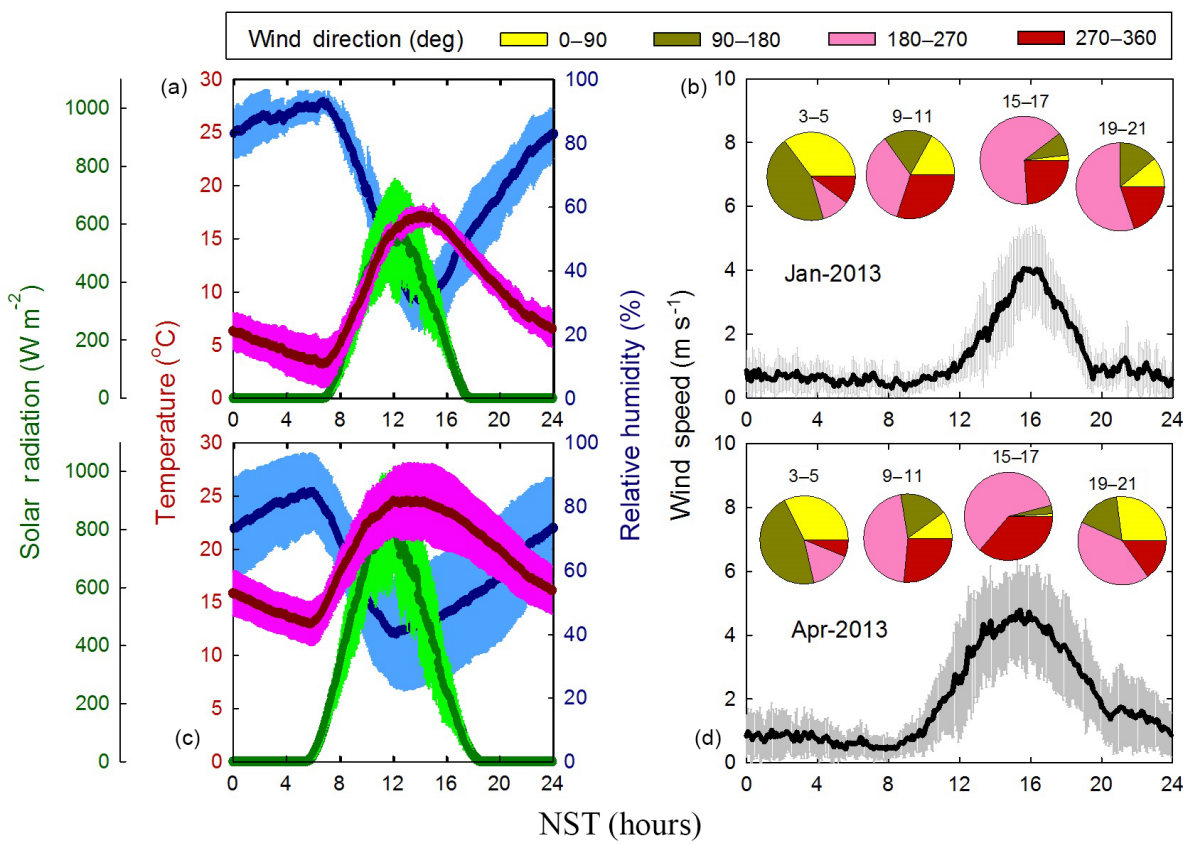

Figure 3. Average diurnal variations in temperature, solar radiation, relative humidity, wind speed and direction at Bode during January (a, b) and April 2013 (c, d). These two months are taken as representative for winter and spring, respectively. (b, d) Wind directions during four time periods (03:00-05:00, 09:00-11:00, 15:00-17:00 and 19:00-21:00 h) are shown as pie charts in wind speed plots.

around Bode at $1 \mathrm{~km}$ above ground level for four different months.

\subsection{WRF-Chem simulations}

WRF-Chem version 3.5.1 with two nested domains was used for this simulation. The coarse domain that encompasses the area between $16-43^{\circ} \mathrm{N}$ and $68-107^{\circ} \mathrm{E}$ was used with $15 \mathrm{~km}$ grid spacing, the nested domain that covers the central part of Nepal and the Kathmandu Valley with $3 \mathrm{~km}$ grid spacing, and 31 vertically stretched layers from the ground up to $10 \mathrm{hPa}$ (Mues et al., 2018). The physics options used for this study include the Lin microphysics scheme (Lin et al., 1983), the Grell cumulus parameterization (Grell and Dévényi, 2002), the Rapid Radiative Transfer Model (Iacono et al., 2008) for the longwave and Goddard shortwave schemes (Chou and Suarez, 1994), the Yonsei University boundary layer parameterization (Hong et al., 2006), and the MM5 scheme for the surface layer (Jimenez et al., 2012). The initial and boundary conditions for meteorological fields use the ERAInterim data. Anthropogenic emissions were obtained from the HTAP v2 inventory (http://edgar.jrc.ec.europa.eu/htap v2, last access: 18 January 2017). Emission maps for CO and $\mathrm{NO}_{x}$ are shown in the Supplement (Figs. S1 and S2). The RADM2-SORGAM chemical mechanism is used to represent the gas-phase and aerosol chemistry. The photolysis rates were computed using the Fast Tropospheric Ultraviolet and Visible (FTUV) Radiation Model (Tie et al., 2003; Li et al., 2005). The dry deposition was calculated following the
Wesely (1989) resistance method. Biogenic emissions were computed on-line using the Model of Emissions of Gases and Aerosols from Nature (MEGAN) (Guenther et al., 2006). The biomass burning emissions are based on the Fire INventory from NCAR (FINN) (Wiedinmyer et al., 2011).

\section{Results and discussion}

\subsection{General meteorology}

The Kathmandu Valley is located in the central Himalayan region due north of the IGP and south of the Tibetan Plateau. The valley is influenced by the south Asian monsoon and in general receives most of its precipitation during summer (June-September). The remaining seasons are relatively dry with spring or pre-monsoon seasons (March-May) being the hottest (Panday and Prinn, 2009). Figure 3 shows the diurnal variations in temperature, $\mathrm{RH}$, solar radiation, wind speed and wind direction at Bode during January and April 2013, which are chosen as representative months for winter (January-February) and spring (March-May), respectively. The average daily RH during January $(67 \%)$ was higher than in April (62\%), with the diurnal maximum during early morning hours. During January, high RH in early morning hours (92\% during 05:00-07:00) was associated with the foggy conditions during morning hours. 

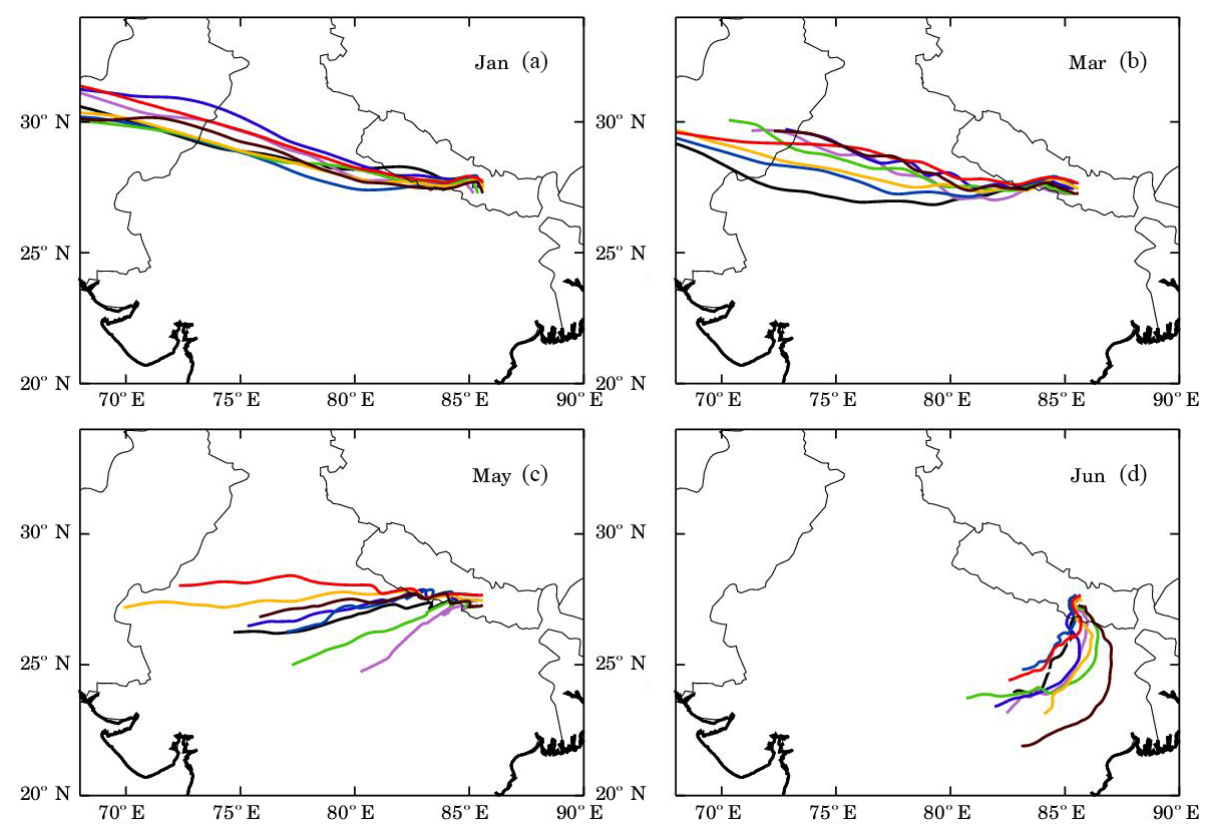

Figure 4. The 5-day nine-point HYSPLIT backward air trajectories over the Bode region during (a) January, (b) March, (c) May and (d) June. The colored trajectories are monthly averaged for each particle during the respective months.

The average temperature and solar radiation were higher in April $\left(20.7^{\circ} \mathrm{C}\right.$ and $\left.\sim 800 \mathrm{~W} \mathrm{~m}^{-2}\right)$ than January $\left(11.4^{\circ} \mathrm{C}\right.$ and $\sim 600 \mathrm{~W} \mathrm{~m}^{-2}$ ). The diurnal variations in temperature showed the highest values during late afternoons, which was a few hours after the peak in diurnal solar radiation. Solar radiation strongly influences the diurnal variations in temperature and other meteorological parameters by surface heating, causing thermals to rise. The wind speeds were the slowest $\left(<1 \mathrm{~m} \mathrm{~s}^{-1}\right)$ during the night and early morning hours, primarily for the easterlies, and the highest wind speeds were observed during middle to late afternoon, primarily for westerlies (4-6 m s${ }^{-1}$ ). These wind patterns were similar in both the months, with April having a slightly longer duration of daytime westerly flow. These wind flows, together with boundary layer dynamics, are responsible for the dispersion and accumulation of pollutants during the course of a day.

The other sites in the Indian region, namely, Pantnagar and Nainital, also show high values of solar radiation and temperature during spring months and the lowest values during the winter season (Ojha et al., 2012; Sarangi et al., 2014; Naja et al., 2016). The Nainital site, which is at a remote mountaintop, experiences moderate northwesterly winds $(\sim$ $2-3 \mathrm{~m} \mathrm{~s}^{-1}$ ) during most of the year, with a prevalence of southeasterly winds during the summer monsoon period. The Pantnagar site is situated in the vicinity of the Himalayan foothills in the IGP and similar seasonal changes in temperature, RH and solar radiation are observed (Ojha et al., 2012). In the summer monsoon season, the lowest levels of $\mathrm{O}_{3}$ and $\mathrm{CO}$ are observed due to the arrival of cleaner marine air masses. During winter months, slow winds, poor ventila- tion and the lowest boundary layer heights are observed, and during the first week of January several cases of widespread fog are also observed.

\subsection{Backward air trajectories}

To understand the wind patterns over Bode, the HYSPLIT model is used to generate backward air trajectories. Figure 4 shows the monthly averaged nine-point trajectories (in different colors) for January, March, May and June around Bode. During the winter and early spring months of January and March, a strong westerly flow is observed, with air masses passing through IGP prior to entering the Nepal region. During late spring (May) these westerly air masses slow down and a slight change in direction is observed as some of the air masses pass through the central part of India. The air masses were observed to be mostly arriving from higher altitudes during winter than during spring (not shown in Fig. 4). Similar behavior of air masses is also observed over Nainital (Kumar et al., 2010). However, during June, the monsoon circulations take over and reversal in wind directions is observed (Fig. 4d). The above features for Bode are similar to those seen over Nainital and Pantnagar. The backward air trajectory analysis for Nainital and Pantnagar shows that longrange transport (westerly wind) is a vital factor during winter. However, air masses mostly circulate over the continental northern Indian region at low altitudes during spring and autumn seasons when local pollution plays an important role (Kumar et al., 2010; Ojha et al., 2012; Naja et al., 2016). 


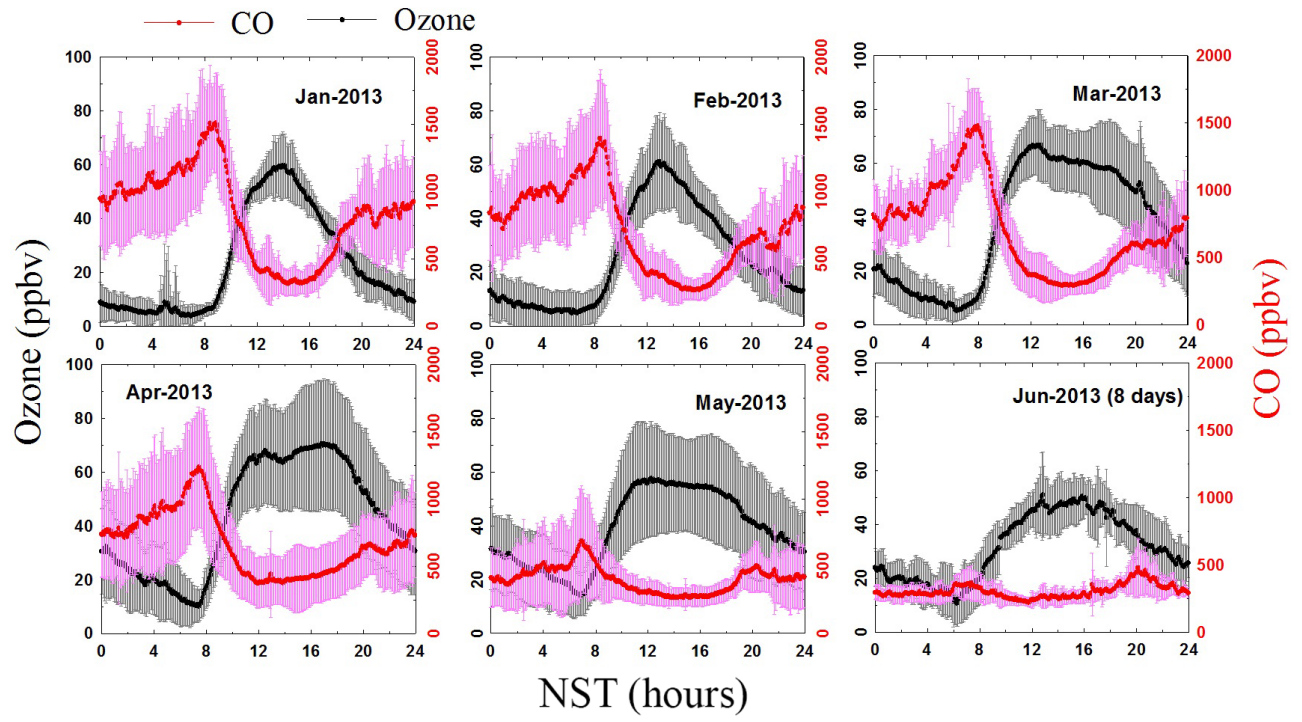

Figure 5. Monthly variations in average diurnal $\mathrm{O}_{3}$ and $\mathrm{CO}$ mixing ratios with $1 \sigma$ spread at Bode during January-June 2013.

\subsection{Variations in ozone at Bode}

The monthly (January to June) average diurnal variations in ozone at Bode are shown in Fig. 5. The diurnal variations in ozone show higher levels during the daytime. This daytime buildup in ozone is consistently observed throughout the observation period, with relatively less buildup during June due to prevailing cloudy-rainy conditions. Additionally, there are only a few days of observations in June, when the campaign ended. The daytime increment in surface ozone is a typical feature of polluted sites and can be associated with daytime photochemical production of ozone from its precursors in the presence of sunlight (e.g., Kleinman et al., 1994). Modelsimulated normalized average diurnal variations also show a clear daytime buildup in ozone during February and May (Fig. S3).

The very low levels of ozone (during winter months) were observed during nighttime, which can be attributed to titration of $\mathrm{O}_{3}$ by NO. The boundary layer measurements made using a ceilometer during the campaign suggest lower heights during nighttime (Fig. 6) with very low ventilation coefficients (VCs) during winter (Mues et al., 2018). The sampling inlet for the gaseous measurements was on the rooftop about $20 \mathrm{~m}$ from the ground level; thus the possibility of loss of ozone due to surface deposition in the highly stratified nighttime boundary layer should be much less. Unfortunately, observations of $\mathrm{NO}$ and $\mathrm{NO}_{2}$ are not available during the campaign but some information about the levels of these species can be obtained from the previous studies. $\mathrm{Pu}$ dasainee et al. (2006) measured the $\mathrm{NO}$ and $\mathrm{NO}_{2}$ during winter of 2003-2004. Yu et al. (2009) also measured NO, $\mathrm{NO}_{2}$ and HONO during a similar period and showed two peaks in the morning (07:00-08:00) and evening (19:00-20:00) in $\mathrm{NO}$, with maximum levels reaching as high as $60 \mathrm{ppb}$. Al- though the results are almost a decade old and the difference in $\mathrm{O}_{3}$ magnitude is also observed (Fig. S4), we expect the increase in NO levels over the valley because satellite-retrieved tropospheric column $\mathrm{NO}_{2}$ shows an increase over this region (Fig. S4).

Just around sunrise, a dip in ozone levels was observed. A similar dip in ozone was observed at an urban site in India (Lal et al., 2000), which is suggested to be due to its reaction with $\mathrm{NO}$ and $\mathrm{NO}_{2}$. Since observations of $\mathrm{NO}, \mathrm{NO}_{2}, \mathrm{NO}_{3}$ and $\mathrm{N}_{2} \mathrm{O}_{5}$ are not made during the campaign, we have employed model results to explain this feature. Figure 7 shows modelsimulated average diurnal variations in $\mathrm{NO}, \mathrm{NO}_{2}, \mathrm{NO}_{3}$ and $\mathrm{N}_{2} \mathrm{O}_{5}$ during February and May 2013. NO mixing ratios are close to zero during the nighttime because it rapidly reacts with $\mathrm{O}_{3}$ to form $\mathrm{NO}_{2}$, which also explains higher $\mathrm{NO}_{2}$ levels during nighttime. $\mathrm{NO}_{3}$ and $\mathrm{N}_{2} \mathrm{O}_{5}$ also show higher levels during nighttime because of the reactions of $\mathrm{NO}_{2}$ with $\mathrm{O}_{3}$ and $\mathrm{NO}_{2}$ with $\mathrm{NO}_{3}$, respectively. The sharp morning increase in $\mathrm{NO}$ mixing ratios correlates strongly with the sharp decrease in $\mathrm{NO}_{3}$ and $\mathrm{N}_{2} \mathrm{O}_{5}$ mixing ratios, especially during February, indicating that photodissociation of $\mathrm{NO}_{3}$ $(\lambda<670 \mathrm{~nm})$ and $\mathrm{N}_{2} \mathrm{O}_{5}(280<\lambda<380 \mathrm{~nm})$ releases NO back into the atmosphere. It is evident that $\mathrm{NO}_{3}$ and $\mathrm{N}_{2} \mathrm{O}_{5}$ peak prior to $\mathrm{NO}$ and $\mathrm{NO}_{2}$ and later they are removed.

At Bode, higher springtime levels of ozone with a broader peak were observed when compared with winter months; this can be attributed to the increase in incoming solar radiation, which in turn increases the photochemical production of ozone. The role of air masses (local vs. regional contribution) will be discussed later in subsequent sections in which differences in winter and spring variations will be clearer. The nighttime ozone mixing ratios during the campaign are the lowest during the winter season. During this period, lower boundary layer height was also observed (Fig. 6) (Mues et 


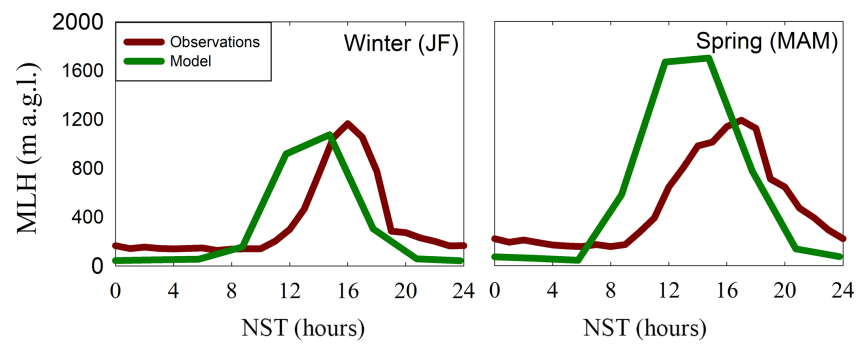

Figure 6. Observed (red) and model-simulated (green) boundary layer height during winter and spring at Bode.

al., 2018). The VC is a measure of transport and/or mixing of pollutants in the boundary layer. Due to very low wind speeds $\left(<1 \mathrm{~m} \mathrm{~s}^{-1}\right)$ and shallow boundary layer height during the night, low $\mathrm{VC}\left(<100 \mathrm{~m}^{2} \mathrm{~s}^{-1}\right)$ were observed during this season (Fig. S5).

\subsection{Variations in $\mathrm{CO}$ and hydrocarbons at Bode}

The monthly average diurnal variations in CO showed two peaks, one during the morning and the other in the evening hours (Fig. 5). The monthly mean values of $\mathrm{O}_{3}$ and $\mathrm{CO}$ with standard deviation, maximum and minimum are given in Table 1. Averages of both these gases in four time periods are also given in Table 2. Diurnal variation in $\mathrm{CO}$ with two peaks is a typical pattern over a polluted site and such variations have been reported at different south Asian urban sites, e.g., Ahmedabad (Lal et al., 2000), Kanpur (Gaur et al., 2014), Pune (Beig et al., 2007), Santiago de Chile (Rappenglück et al., 2005) and Chicago (Pun et al., 2003). The major sources for $\mathrm{CO}$ in the valley are vehicular emissions, brick kiln emissions, domestic burning of biofuels for cooking and heating, and garbage burning. Out of these, vehicular emissions, cooking and heating occur largely two times a day, morning and evening, but with some time differences. Additionally, the nighttime and early morning hours are characterized by very slow wind speeds and a shallower boundary layer along with poor mixing.

Note that CO levels during morning peaks are greater than those during the evening. Such higher peaks during morning times than those during evening times have also been observed by Panday and Prinn (2009) and have been explained on the basis of overnight accumulation of $\mathrm{CO}$ emissions. During daytime the emissions are countered by the boundary layer evolution and dynamic processes such as flushing of $\mathrm{CO}$ and other pollutants by westerly winds (Figs. 1 and 3) blowing eastwards across the mountain passes in the valley throughout the afternoon. The chemical loss of $\mathrm{CO}$ via reaction with $\mathrm{OH}$ radicals could also contribute to lower daytime $\mathrm{CO}$ levels. However, $\mathrm{OH}$ measurements are not made during the campaign and it is not possible to confirm this aspect.

The mixing layer starts evolving after sunrise and reaches its peak median values of about 900-1200 m during the win- ter and spring seasons (Mues et al., 2018). The VC estimated (with $15 \mathrm{~m}$ wind data) during the daytime suggested vertical mixing could occur from mid-afternoon until early evening hours when consistently high VC $\left(>1000 \mathrm{~m}^{2} \mathrm{~s}^{-1}\right)$ was observed (Fig. S3). During this period the daily maximum wind speeds (4-5 $\mathrm{m} \mathrm{s}^{-1}$ at 15:00-17:00), which were mostly westerly, were observed, and further decreases in the CO levels with daily minimum levels (148-218 ppbv) were also observed during this period. Due to relatively higher wind speeds and associated advection before the evening hours, the CO mixing ratios at 19:00-20:00 are about 30$50 \%$ lower than for the morning hours.

In addition to $\mathrm{CO}$, observations of VOCs made at Bode (Sarkar et al., 2016) also showed similar diurnal variations with two peaks and levels up to about 15 ppbv. Similar to $\mathrm{CO}$, many VOCs (e.g., acetonitrile, benzene, furan) showed higher levels during the morning, when compared to the evening peaks. We also collected one air sample almost every day during 30 December 2012-14 January 2013 and analyzed them for light NMHCs $\left(\mathrm{C}_{2}-\mathrm{C}_{5}\right)$ and for $\mathrm{CH}_{4}-\mathrm{CO}$. Average values along with standard deviation, minimum, maximum and number of samples are given in Table 3. Average methane levels for the measurement period at Bode are $2.55 \pm 0.12 \mathrm{ppmv}$, which is much higher than the global average and about $28 \%$ and $27 \%$ higher than measured the Northern Hemisphere background site at Mauna Loa $(1.84 \mathrm{ppmv})$ and at the remote site Mt. Waliguan, China (1.87 ppmv), respectively (www.esrl.noaa.gov, last access: 10 March 2018). The average values of other hydrocarbons varied from about 1 to about $4.4 \mathrm{ppbv}$. The maximum value is observed for propane (15.48 ppbv) and acetylene (14.35 ppbv). These highest mixing ratios are observed on 7 January 2013.

The mixing ratios of eight light NMHCs at Bode are relatively higher (ppbv) than those observed at Nainital (0.8$2.2 \mathrm{ppbv}$ ) and comparable with those at Pantnagar-Haldwani (0.8-3.7 ppbv and 1.6-4.2 ppbv, respectively). Additionally, unlike Bode, none of these sites in India showed NMHC mixing ratios exceeding $10 \mathrm{ppbv}$. The methane mixing ratio is also higher at Bode ( $2.55 \mathrm{ppmv})$ than that observed at Nainital (1.89 ppmv). Figure 8 shows a comparison of the contribution of eight light NMHCs at Bode, Nainital, Pantnagar (including another town, Haldwani) (Sarangi et al., 2016) and Kanpur (Lal et al., 2008). Bode data are for DecemberJanuary, while data from the rest of the three sites are from December. Composition at Bode shows a difference from that at Indian sites. Propane (20\%) and $n$-butane $(13.5 \%)$ show a greater contribution, while the contribution of $i$ pentane $(4.2 \%)$ is significantly lower at Bode when compared with India sites. A greater contribution of propane and $n$-butane indicates leakages of LPG in the Kathmandu Valley. 

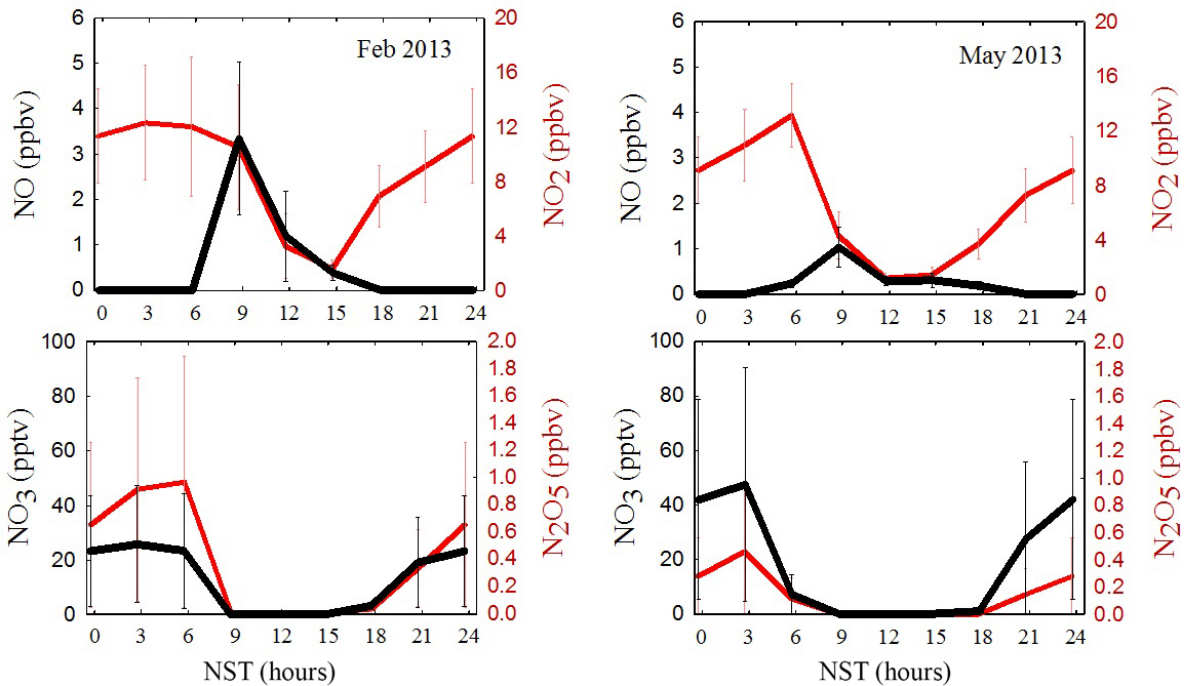

Figure 7. Model-simulated average diurnal variations in $\mathrm{NO}, \mathrm{NO}_{2}, \mathrm{NO}_{3}$ and $\mathrm{N}_{2} \mathrm{O}_{5}$ during February and May 2013.

Table 1. Monthly variations in $\mathrm{O}_{3}$ and $\mathrm{CO}$ over Bode, Nepal, during January-June 2013.

\begin{tabular}{lrrrrr}
\hline Month & Ozone (ppbv) & Max/min (ppbv) & $\begin{array}{r}\text { Daytime average ozone } \\
\text { ppbv }(1100-1700 \mathrm{~h})\end{array}$ & CO (ppbv) & Max/min (ppbv) \\
\hline Jan & $23.5 \pm 19.9$ & $87.1 / 1.4$ & $49.8 \pm 10.2$ & $832 \pm 422$ & $2323 / 218$ \\
Feb & $25.6 \pm 20.4$ & $95 / 1.2$ & $49.9 \pm 13.9$ & $717 \pm 397$ & $2182 / 162$ \\
Mar & $37.4 \pm 23$ & $105.9 / 1.2$ & $61.8 \pm 12.0$ & $698 \pm 364$ & $2011 / 158$ \\
Apr & $43.5 \pm 26.6$ & $116.2 / 1.4$ & $67.0 \pm 20.4$ & $667 \pm 372$ & $1969 / 175$ \\
May & $38.6 \pm 21.4$ & $111.1 / 1.9$ & $55.1 \pm 18.9$ & $401 \pm 213$ & $1656 / 146$ \\
Jun & $31.1 \pm 16$ & $68.4 / 1.7$ & $46.5 \pm 8.5$ & $303 \pm 85$ & $676 / 166$ \\
\hline
\end{tabular}

\subsection{Correlation between ozone and $\mathrm{CO}$}

It has been discussed in the previous section that $\mathrm{O}_{3}$ and $\mathrm{CO}$ show some contrasting diurnal variations. Here we discuss the correlation between $\mathrm{O}_{3}$ and $\mathrm{CO}$ during different months (Fig. 9). The highest negative correlation is seen in the winter period $\left(r^{2}=0.82\right.$ in January and $r^{2}=0.71$ in February) and this negative correlation reduces gradually, with the lowest value in May $\left(r^{2}=0.12\right)$. The reduction in the tendency of the negative correlation from January to May could be due to changes in emission patterns and the boundary layer mixing. This is discussed further in the subsequent paragraphs. Hourly average $\mathrm{CO}$ levels show a systematic decrease from $\sim 2300 \mathrm{ppbv}$ in January to about $680 \mathrm{ppbv}$ in June, whereas ozone levels show an increasing tendency. The daytime ozone levels during the spring season are slightly higher ( $\sim 62 \mathrm{ppbv})$ when compared to winter $(\sim 54 \mathrm{ppbv})$. This springtime increase in ozone levels is also reported by several other studies in the northern part of the Indian subcontinent (Kumar et al., 2010; Ojha et al., 2012; Kumar et al., 2013; Gaur et al., 2014). The higher values of CO during the winter season can be attributed to an increase in its emissions (domestic and garbage burning to keep warm in the winter season) and their inefficient dilution due to poor mixing and a shallower boundary layer (Mues et al., 2018). However, during the spring season, a greater and relatively wellmixed daytime boundary layer leads to lower $\mathrm{CO}$ levels. As mentioned previously, the role of $\mathrm{OH}$ chemistry could be an additional contributor in lower CO levels in spring. Modelsimulated $\mathrm{OH}$ levels are found be higher in May, when compared with February. This would suggest great chemical loss of $\mathrm{CO}$ in spring (May).

Figure 10 shows daily variations in $\mathrm{O}_{3}$ and $\mathrm{CO}$ during four different times, i.e., 03:00-05:00, 07:30-08:30, 13:0015:00 and 22:00-23:00 h. We consider that 03:00-05:00 and 22:00-23:00 h would provide information for the periods when photochemical production of ozone is absent, while 13:00-15:00 $\mathrm{h}$ can be used to understand the behavior during the periods of high photochemical activity and a fully evolved daytime mixed layer. Variations during 07:30 08:30 $\mathrm{h}$ will provide information during the morning period. The stable nocturnal boundary layer starts evolving during morning hours and air masses close to the surface begin to mix with air at higher heights. In general, $\mathrm{CO}$ levels (blue line) show a decrease from January to June during 03:0005:00, 07:30-08:30 and 22:00-23:00 h, while they do not 
Table 2. Average (avg), standard deviation (SD), maximum (max), minimum (min) and daily counts of $\mathrm{O}_{3}$ and $\mathrm{CO}$ values during four time periods for the entire observational period (January-June 2013).

\begin{tabular}{rlrrrr}
\hline \multicolumn{2}{c}{ Time period } & $03: 00-05: 00 \mathrm{~h}$ & $07: 30-08: 30 \mathrm{~h}$ & $13: 00-15: 00 \mathrm{~h}$ & $22: 00-23: 00 \mathrm{~h}$ \\
\hline \multirow{2}{*}{ Ozone } & Avg (ppbv) & 13.1 & 13.9 & 58.9 & 27.8 \\
& SD (ppbv) & 1.2 & 1.7 & 10.0 & 7 \\
& Max (ppbv) & 54.0 & 52.5 & 102.4 & 70.8 \\
& Min (ppbv) & 1.8 & 2.0 & 25.9 & 1.4 \\
& Counts & 158 & 158 & 158 & 158 \\
\hline CO & Avg (ppbv) & 833.8 & 1103.2 & 325.4 & 626.1 \\
& SD (ppbv) & 292.6 & 380.3 & 98.3 & 306 \\
& Max (ppbv) & 1770.0 & 2430.0 & 910.0 & 1820.0 \\
& Min (ppbv) & 150.0 & 160.0 & 160.0 & 190.0 \\
& Counts & 159 & 158 & 159 & 158 \\
\hline
\end{tabular}

Table 3. Average, standard deviation, minimum and maximum mixing ratios (ppbv, except for $\mathrm{CH}_{4}$, which is in parts per million by volume) of $\mathrm{CH}_{4}, \mathrm{CO}$ and eight $\left(\mathrm{C}_{2}-\mathrm{C}_{5}\right)$ light NMHCs from the analysis of daily air sample collection from 30 December 2012 to 14 January 2013. Percentage contribution for each NMHC to the total of measured NMHCs is also given.

\begin{tabular}{lrrrrrr}
\hline Gases & Average & Standard deviation & Minimum & Maximum & \% contribution & Analysis \\
\hline Methane & 2.55 & 0.12 & 2.39 & 2.87 & - & 15 \\
CO & 392.5 & 109.3 & 272 & 588.8 & - & 16 \\
Ethane & 3.49 & 1.24 & 1.01 & 6.35 & 15.8 & 15 \\
Ethene & 2.84 & 2.37 & 0.31 & 9.69 & 12.9 & 15 \\
Propane & 4.41 & 4.14 & 0.44 & 15.48 & 20.0 & 13 \\
Propene & 1.06 & 0.91 & 0.28 & 3.86 & 4.8 & 13 \\
$i$-Butane & 2.26 & 1.93 & 0.24 & 7.78 & 10.3 & 13 \\
Acetylene & 4.08 & 3.87 & 0.34 & 14.35 & 13.5 & 14 \\
$n$-Butane & 2.96 & 1.80 & 0.18 & 5.81 & 18.5 & 14 \\
$i$-Pentane & 0.92 & 0.84 & 0.15 & 2.63 & 4.2 & 14 \\
\hline
\end{tabular}

show significant changes during 13:00-15:00 h. In contrast, ozone levels (red lines in Fig. 10) increase from January to May-June during all four time periods. The highest noontime ozone level is observed to be about 80 ppbv during January to March, which increases to about $102 \mathrm{ppbv}$ during April-May. The noontime ozone level comes down to about $46 \mathrm{ppbv}$ in June, which is mainly due to the beginning of the monsoon season, which is characterized by the arrival of cleaner air from the oceanic regions of the Bay of Bengal, the Arabian Sea and the Indian Ocean.

The increase in ozone from January to May is rather more during nighttime or early morning hours, when photochemical production of ozone is absent. This suggests an enhancement in the background ozone levels. Hence, the average ozone value (13.1 $\pm 1.2 \mathrm{ppbv})$ during the early morning period of 03:00-05:00 h would most likely represent background ozone levels for this region. However, the emissions directly influence the $\mathrm{CO}$ levels. Hence, the estimated $\mathrm{CO}$ mixing ratio (325.4 $\pm 98.3 \mathrm{ppbv})$ during noontime (13:0015:00 h) could be considered to be background levels for the Bode region. The noontime boundary layer at Bode is assumed to be well mixed and the fast westerly flows across the valley reduce the direct sampling of air masses at Bode from its immediate emission sources scattered in the valley.

Figure 10 also shows correlation between $\mathrm{O}_{3}$ and $\mathrm{CO}$ for different time periods. Weak negative correlation is seen during the early morning (03:00-05:00 and 07:30-08:30 h) or nighttime hours (22:00-23:00 h). During nighttime and early morning hours, the lowest boundary layer height (150 $200 \mathrm{~m}$ ) was observed. In the urban or semi-urban environment of Kathmandu Valley, where $\mathrm{NO}_{x}$ levels are not lower (Pudasainee et al., 2006), ozone titration takes place throughout the nighttime. Figure 10 also indicates the increase in overnight $\mathrm{CO}$ levels, which peaked during morning hours. These contrasting variations tend to show the negative correlations. However, a slight positive correlation is observed around noon (13:00-15:00 h), which is similar to what is generally observed at high-altitude sites (Kajii et al., 1998; Tsutsumi and Matsueda, 2000; Naja et al., 2003; Sarangi et al., 2014) and cleaner sites (e.g., island sites; Pochanart et al., 1999). 


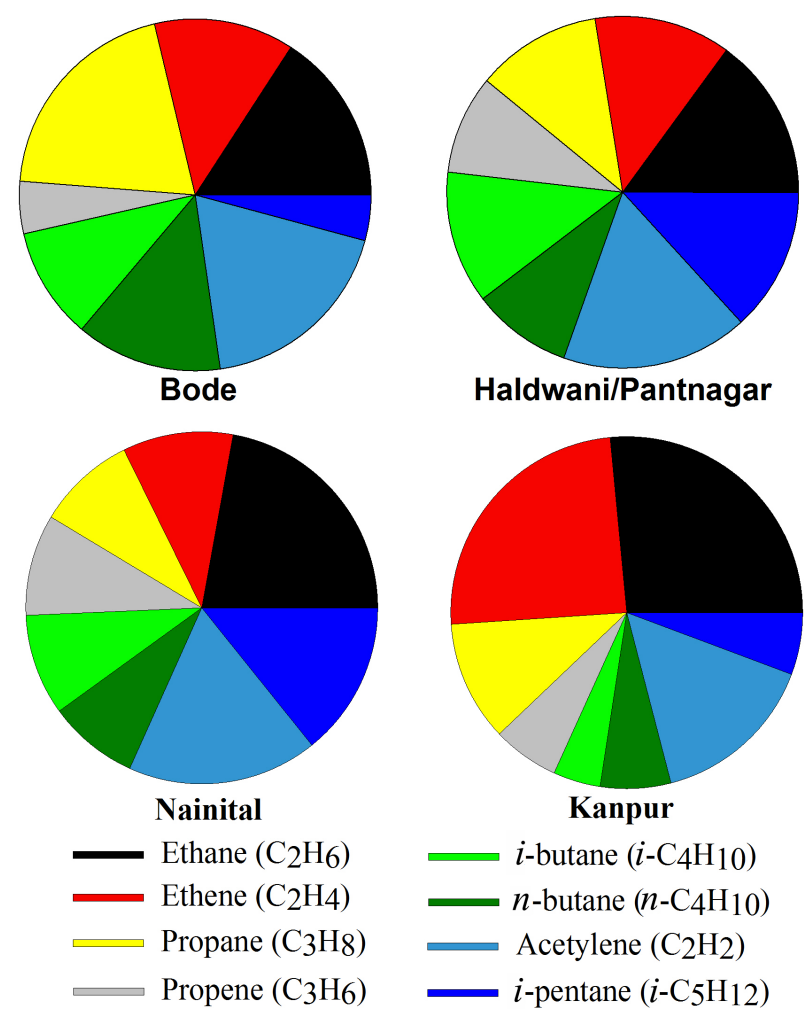

Figure 8. Contribution of eight light non-methane hydrocarbons (NMHCs) to the total NMHCs at Bode, Pantnagar-Haldwani, Nainital and Kanpur in December. Bode includes January data too.

\subsection{Regional distribution of $\mathrm{O}_{3}$ and $\mathrm{CO}$ during SusKat}

Apart from $\mathrm{O}_{3}$ and $\mathrm{CO}$ observations at Bode, simultaneous observations of these two gases were also made at the central Himalayan site in India (Nainital) and at a site in the Himalayan foothills in the IGP region (Pantnagar) and are discussed in this section. The wind patterns over Pantnagar and Nainital, despite the difference in altitude, are mostly northerly or northwesterly during winter (Kumar et al., 2010; Ojha et al., 2012; Sarangi et al., 2014). Further, both sides receive polluted air masses from the IGP during spring. Whereas the cleaner marine air masses arrive at these sites during the summer monsoon season. Average diurnal patterns in $\mathrm{O}_{3}$ and $\mathrm{CO}$ mixing ratios are similar at Bode and Pantnagar, with twin peaks in $\mathrm{CO}$ and high daytime levels of $\mathrm{O}_{3}$. However, different variations (Fig. 11) are observed at Nainital (green line), which being a remote high-altitude site does not show any daytime photochemical buildup or nighttime loss in ozone. Further, the daytime ozone levels at Bode are higher than those at Pantnagar during winter while they are comparable during spring. Additionally, $\mathrm{CO}$ levels are also higher at Bode than those at Pantnagar during winter (Fig. 11). A comparison of surface ozone measurements at Kanpur (India) showed a relatively better agreements with Pantnagar (India) while measurement at Paknajol (Nepal) showed better agreement with Bode (Nepal) during both seasons (winter and spring) (Fig. 11), indicating the differences in emission sources of the Kathmandu Valley and the IGP.

The changes in ozone increase and decrease rates $\left(\mathrm{ppbvh}^{-1}\right)$ are analyzed for all five sites. Generally, the ozone increase and decrease rates are nearly symmetric during morning and evening at an urban site. However, it is asymmetric, with slower changes occurring during the afternoon-evening at rural or semi-urban sites (Naja and Lal, 2002). Ozone production is strongly dependent on the amount of precursor gas and available sunlight. Conversely, evening ozone loss depends mainly upon its titration with NO, in addition to surface deposition. This rate of change of ozone during morning and evening hours has been used as an indicator of chemical environment (rural or urban) over a site (e.g., Naja and Lal, 2002). Below, we discuss calculated ozone increase and decrease rates.

Figure 12 shows that the wintertime rate of ozone increase in the morning hours is much higher at Bode (about $17 \mathrm{ppbvh}^{-1}$ ) when compared to Pantnagar (about $9 \mathrm{ppbv} \mathrm{h}^{-1}$ ). This suggests a more rapid ozone buildup at Bode than at Pantnagar. In contrast, the ozone decrease rate is lower at Bode (5-6 $\mathrm{ppbv} \mathrm{h}^{-1}$ ) when compared to the decrease rate at Pantnagar (about $14 \mathrm{ppbvh}^{-1}$ ) during spring. This suggests rather slower ozone loss at Bode via NO titration, indicating a somewhat less polluted environment in Bode during spring. However, this does not necessarily mean that $\mathrm{NO}_{x}$ emissions are lower in the Kathmandu Valley. NO levels are reported to be as high as $60 \mathrm{ppbv}$ (Yu et al., 2009). Another process driven by diurnal variations in winds could lead to slower evening ozone loss rates. Faster afternoon westerly winds flush the pollutants out of the valley every day, leaving less $\mathrm{NO}_{x}$ to titrate ozone during evening hours. In contrast, slower winds at night allow overnight accumulation of precursor gases in the nocturnal boundary layer of the Kathmandu Valley that in turn can potentially contribute to next-morning ozone buildup. Similar to the diurnal variations in average ozone, diurnal patterns in ozone change rates are similar at Pantnagar and Kanpur.

Analysis of ozone observations including backward air trajectories at Nainital in the central Himalayas shows that the major role of regional and local pollution is in spring when regionally polluted ozone levels are estimated to be $47.1 \pm 16.7 \mathrm{ppbv}$ (Kumar et al., 2010). During spring, net ozone production over the northern Indian subcontinent is estimated to be $3.2{\mathrm{ppbv} d a y^{-1}}^{-1}$ in regionally polluted air masses in spring but no clear buildup is seen at other times of year. The role of long-range transport is shown to be important in winter, with a contribution of about $8-11$ ppbv of ozone.

Shorter duration of solar heating during winter leads to weaker dynamical processes including convective mixing of pollutants, which in turn confines the pollutants close to the surface. Additionally, the Kathmandu Valley is isolated inside the Himalayas and the only way for pollutants to reach 

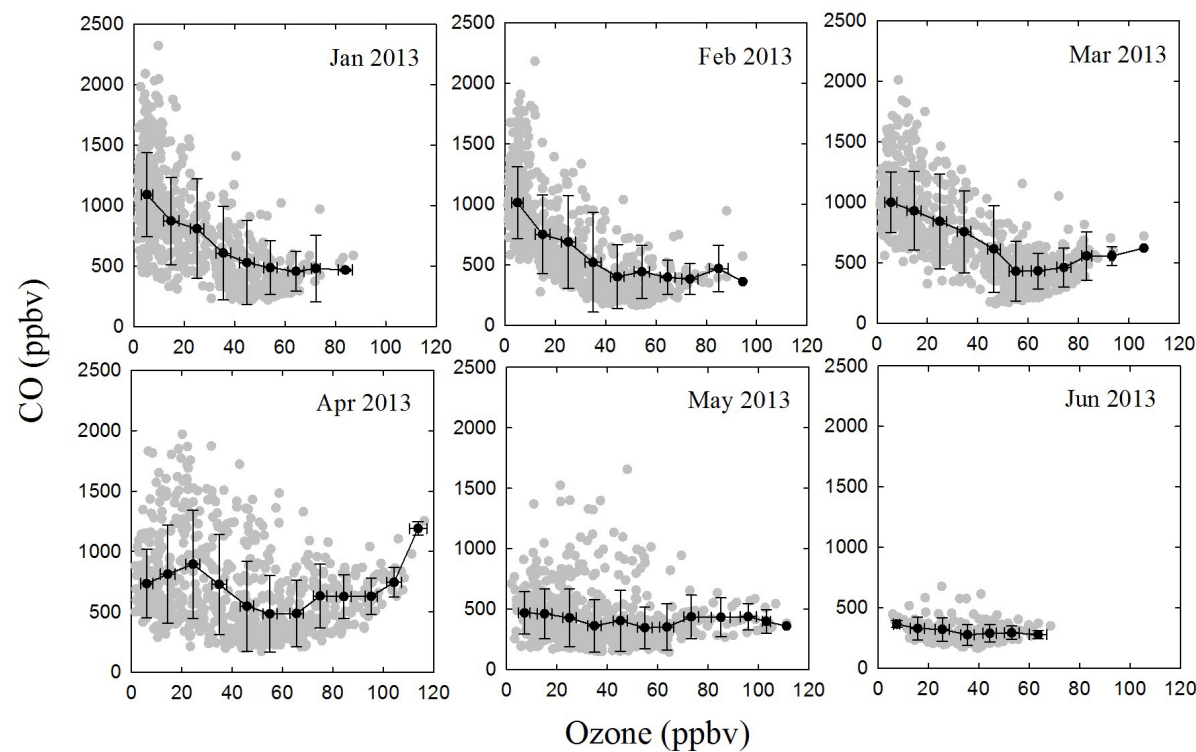

Figure 9. Relation between ozone and CO from January 2013 to June 2013 at Bode. Grey dots are hourly average data and black filled dots are $10 \mathrm{ppbv}$ binned data averaged with respect to ozone. The spread around the mean value is $1 \sigma$.
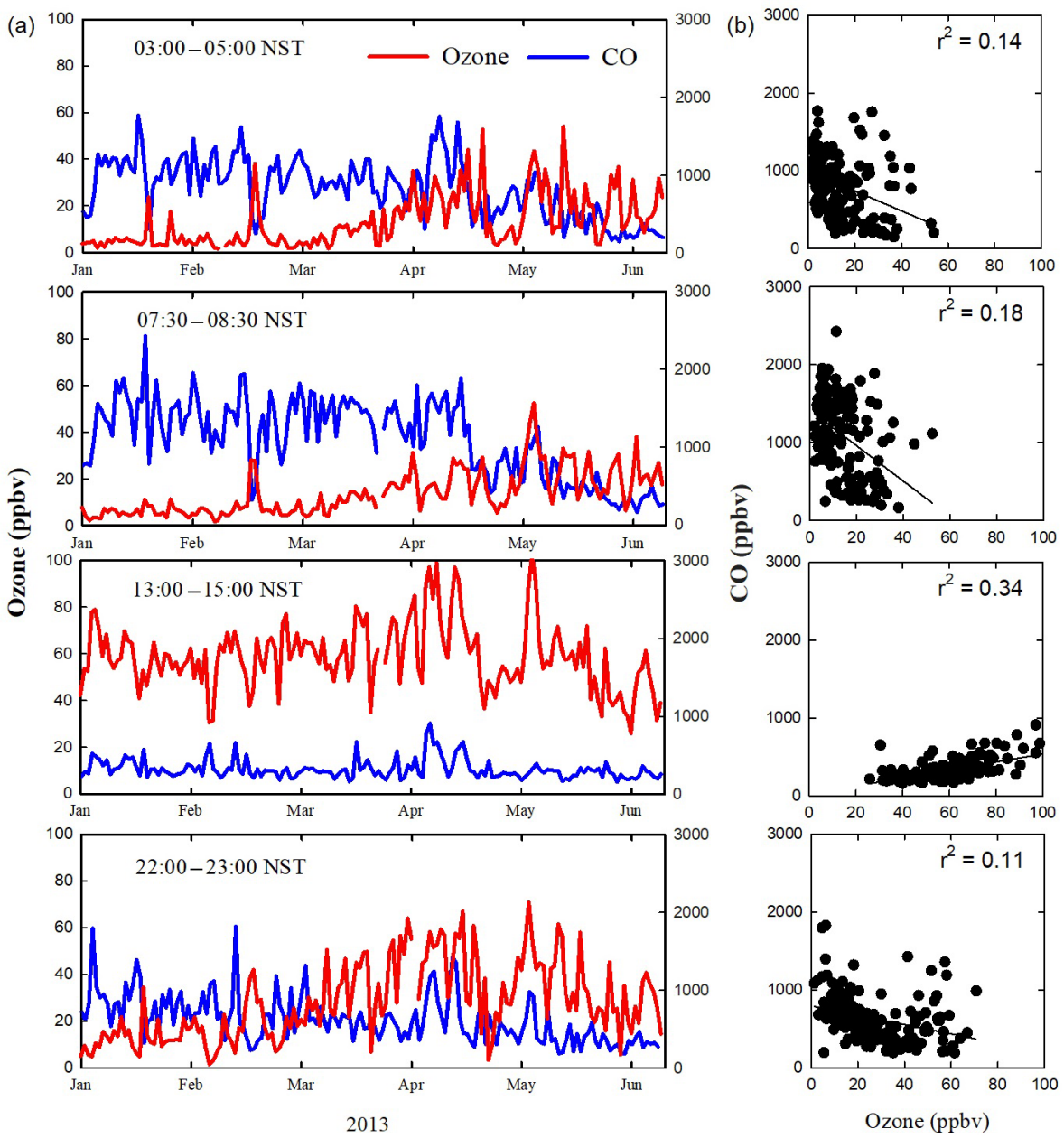

Figure 10. (a) Variations in ozone and CO during four time periods at Bode, Nepal. Correlation among them is also shown (b). 


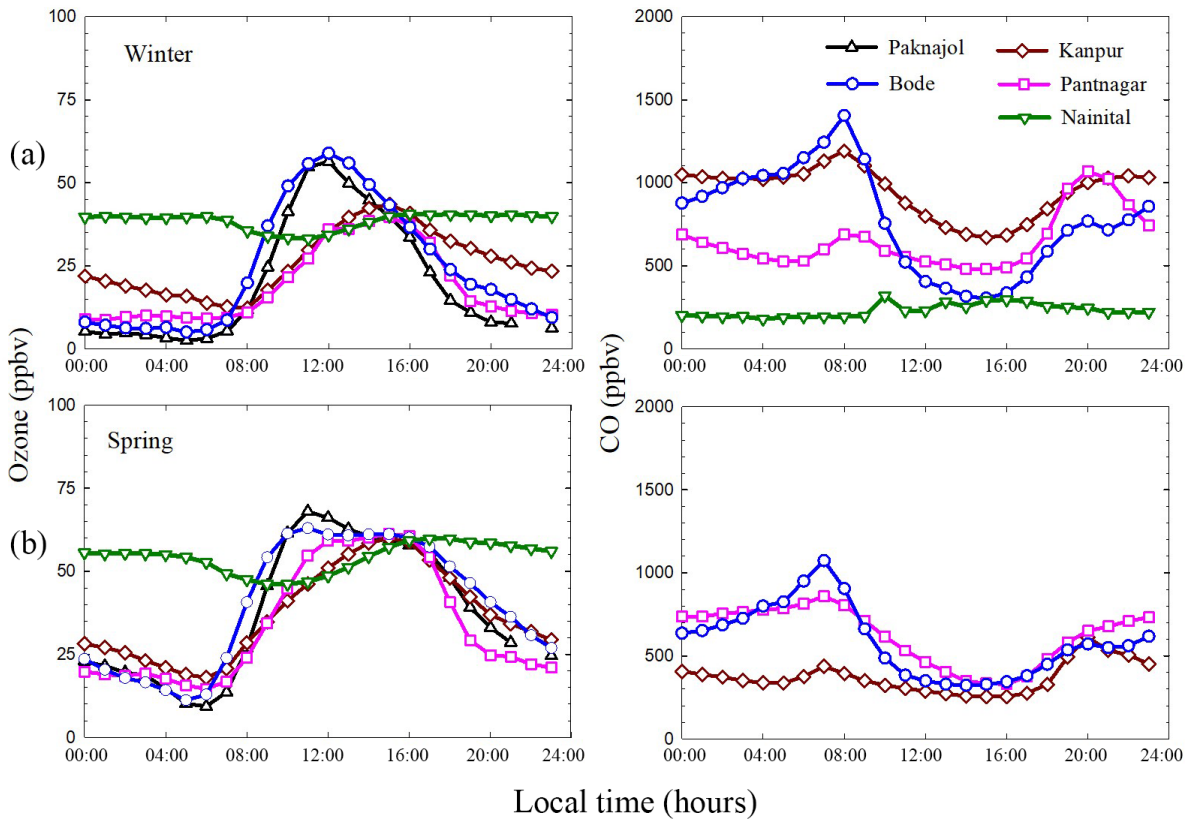

Figure 11. Averaged diurnal variations (winter (a); spring (b)) in ozone and CO at Bode, Pantnagar and Nainital. Surface ozone observations at Kanpur (data from Gaur et al., 2014) and Paknajol (data from Putero et al., 2015) are also shown for the comparison. CO measurements were not available at Nainital during the spring season.

the area is via either upslope flow of polluted air masses through the mountain valleys or arrival of polluted regional air masses from the air aloft. Thus, the wintertime $\mathrm{O}_{3}$ and $\mathrm{CO}$ mixing ratios at Bode are unlikely to be influenced by IGP pollution. Further similar trapping of pollutants during winter is also reported by previous studies performed over this region (Panday and Prinn, 2009). However, intense heating and stronger convective mixing could induce the IGP outflow to influence this valley region during spring. Springtime ozone enhancement, due to IGP outflow, in the tropical marine region surrounding India has already been observed (Lal et al., 2013).

\subsection{Influences of springtime northern Indian biomass burning}

Every year northern Indian biomass burning emits large quantities of trace gases and aerosols and significantly affects the regional distribution of several trace species (Kumar et al., 2011; Sinha et al., 2014; Putero et al., 2014; Bhardwaj et al., 2016; Kumar et al., 2016). These studies showed the enhancement in $\mathrm{O}_{3}$ and $\mathrm{CO}$ levels due to crop residue and forest fire burning in the IGP during pre- and post-monsoon seasons. To investigate the influences of biomass burning on the surface ozone and $\mathrm{CO}$ mixing ratios over Bode, a time series of high-confidence (confidence $>80 \%$ ) fire counts over the northern Indian subcontinent $\left(25-35^{\circ} \mathrm{N}, 70-95^{\circ} \mathrm{E}\right)$ were analyzed. Based on MODIS fire counts, the fire activity period is chosen to be 3 April to 31 May 2013.
A high-fire-activity period (HFAP) is defined when a 3day running mean of fire counts exceeds the median fire counts during the fire activity period (Kumar et al., 2011). The low-fire-activity period (LFAP) is defined as 1-31 March when very low fire counts are observed over the northern Indian subcontinent. The changes in surface ozone and $\mathrm{CO}$ mixing ratios during these two periods (HFAP and LFAP) are shown in Fig. 13d, f. The average fire emissions over the Kathmandu region $\left(27-28^{\circ} \mathrm{N}, 85-86^{\circ} \mathrm{E}\right)$ using the GFED v4.0 emission inventory are also calculated and shown in Fig. 13b. Since the HFAP is almost 4 weeks long, two different peaks in ozone and $\mathrm{CO}$ mixing ratios during April and May are selected (see highlighted peaks in Fig. 13). During both the periods a prior increase in fire counts was observed, which is followed by higher levels of ozone and $\mathrm{CO}$ mixing ratios. Another reason to separately study these cases is fire locations during these two periods. A high $\mathrm{CO}$ and $\mathrm{O}_{3}$ cases in April are shown to be induced by the fires that are mostly located in the Nepal region (dark red), while fire activity was very low in the northern part of the IGP in April (Fig. S6). Conversely, during the May event (orange), a high increase in fire counts $(\sim 2.5$-fold $)$ is observed over the northern Indian subcontinent during the HFAP (Fig. S6) and very little fire was seen in the Nepal region. Therefore, these two cases could be studied separately to assess impacts of biomass burning over Bode and other sites. The changes during HFAP, LFAP and the above two event cases in April and May are shown in Table 4. 
Table 4. The average $\mathrm{O}_{3}$ and $\mathrm{CO}$ mixing ratios at Bode, Nainital and Pantnagar with GFED average biomass burning emissions over the Kathmandu region during different periods.

\begin{tabular}{|c|c|c|c|c|c|c|c|c|}
\hline \multirow[t]{2}{*}{ Fire periods } & \multirow[t]{2}{*}{ Fire count } & \multicolumn{2}{|c|}{ Ozone (ppbv) } & \multicolumn{2}{|c|}{$\mathrm{CO}$ (ppbv) } & \multicolumn{3}{|c|}{$\begin{array}{l}\text { Avg. biomass burning } \\
\text { emissions }\left(\mathrm{Tg} \mathrm{day}^{-1}\right)\end{array}$} \\
\hline & & Bode & NTL & Bode & PNT & Total & Crops & Forest \\
\hline LFAP (1-31 Mar) & 5 & 37.4 & 45.2 & 705 & 455 & 8.96 & 2.29 & 5.87 \\
\hline HFAP (Apr-May) & 70 & 43.7 & 63.9 & 504 & 374 & 63.70 & 42.70 & 19.94 \\
\hline $\operatorname{Mar}(20-25)$ & 3 & 34.8 & 46.1 & 693 & 401 & 7.17 & 2.37 & 3.67 \\
\hline Apr (3-6) & 18 & 46.7 & 49.2 & 797 & 250 & 57.74 & 7.48 & 46.46 \\
\hline Apr (11-16) & 27 & 54.0 & 57.9 & 762 & 265 & 52.38 & 7.03 & 44.16 \\
\hline Apr (26-30) & 26 & 33.9 & 45.0 & 505 & 313 & 22.10 & 14.60 & 6.78 \\
\hline May (2-6) & 116 & 58.8 & 74.8 & 625 & 495 & 128.40 & 97.58 & 29.72 \\
\hline
\end{tabular}

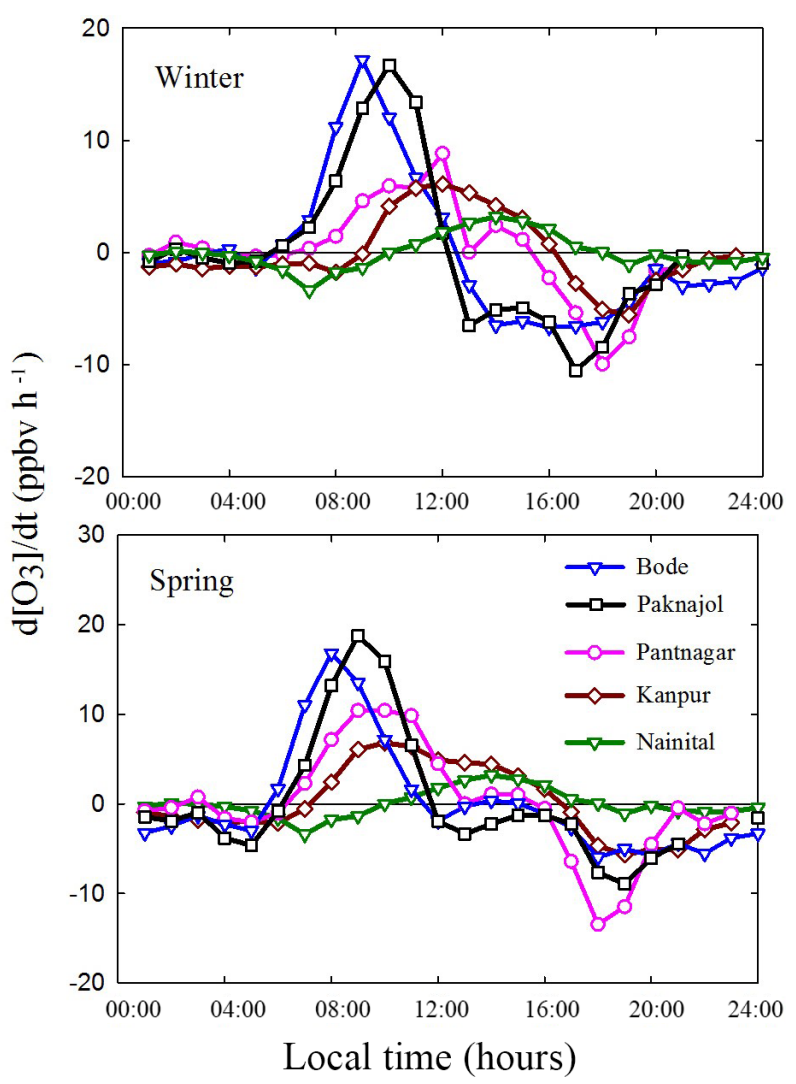

Figure 12. Diurnal variations in the average rate of change of ozone during winter and spring 2013 at Bode (blue), Paknajol (black; Putero et al., 2015), Pantnagar (pink), Kanpur (brown; Gaur et al., 2014) and Nainital (green).

During the first half of April daily averaged CO mixing ratios of $861 \mathrm{ppbv}$ were recorded, which were about $200 \mathrm{ppbv}$ higher than the daily averaged CO levels for April. Ozone mixing ratios during this period were about 9 ppbv higher than the daily averaged ozone levels for April. The spatial maps of MODIS fire counts during the period were also ana- lyzed (Fig. 14, top panel) and an increase in fire counts during the period was observed. Based on MODIS fire counts and $\mathrm{O}_{3}$ and $\mathrm{CO}$ time series at Bode, we classified 20-25 March as a pre-event period and 3-6 and 11-16 April as HFAPs. During the first HFAP, increases of $55 \%$ and $15 \%$ in surface ozone and $\mathrm{CO}$ mixing ratios were observed. The fire maps during this period also indicate that the majority of the fires were occurring near Bode in the Nepal region and are shown in orange in the spatial map (Fig. 14, top panel). The AIRS-retrieved CO mixing ratios at 925 and $850 \mathrm{hPa}$ also indicate an increase in $\mathrm{CO}$ levels near Bode (indicated by black star); however no similar increase is observed in $\mathrm{CO}$ levels near Pantnagar (or IGP). The majority of air masses at $1 \mathrm{~km}$ a.g.l. (above ground level) prior to arriving to Bode (or Nainital) are westerly and pass through the IGP and northern Indian subcontinent. Since there is almost no fire activity near the Punjab region, we argue that these nearby fires and their associated polluted plumes around the Kathmandu Valley could affect the levels at Bode. Further, GFED biomass burning emissions were used to differentiate different types of biomass burning emissions during this period. During both of the events, the forest fire emissions dominated the total biomass burning emissions over the Kathmandu region. The major land use types in black boxes indicated in Fig. 14 are agricultural land or forests. The meteorological data observed during this period did not show any noticeable differences and boundary layer height during these events was close to monthly average values. Therefore, we can conclude that forest fires occurring in the nearby Kathmandu Valley were responsible for high levels of pollutants during this period.

The second event took place in the first week of May when simultaneous increases in surface $\mathrm{O}_{3}$ and $\mathrm{CO}$ levels at Bode, $\mathrm{O}_{3}$ levels at Nainital, and $\mathrm{CO}$ levels at Pantnagar were observed. During this event, $\mathrm{O}_{3}$ mixing ratios at Bode and Nainital increased by $73 \%$ and $67 \%$, respectively, and $\mathrm{CO}$ mixing ratios at Bode and Pantnagar increased by about $24 \%$ and $58 \%$, respectively. The MODIS fire maps during 


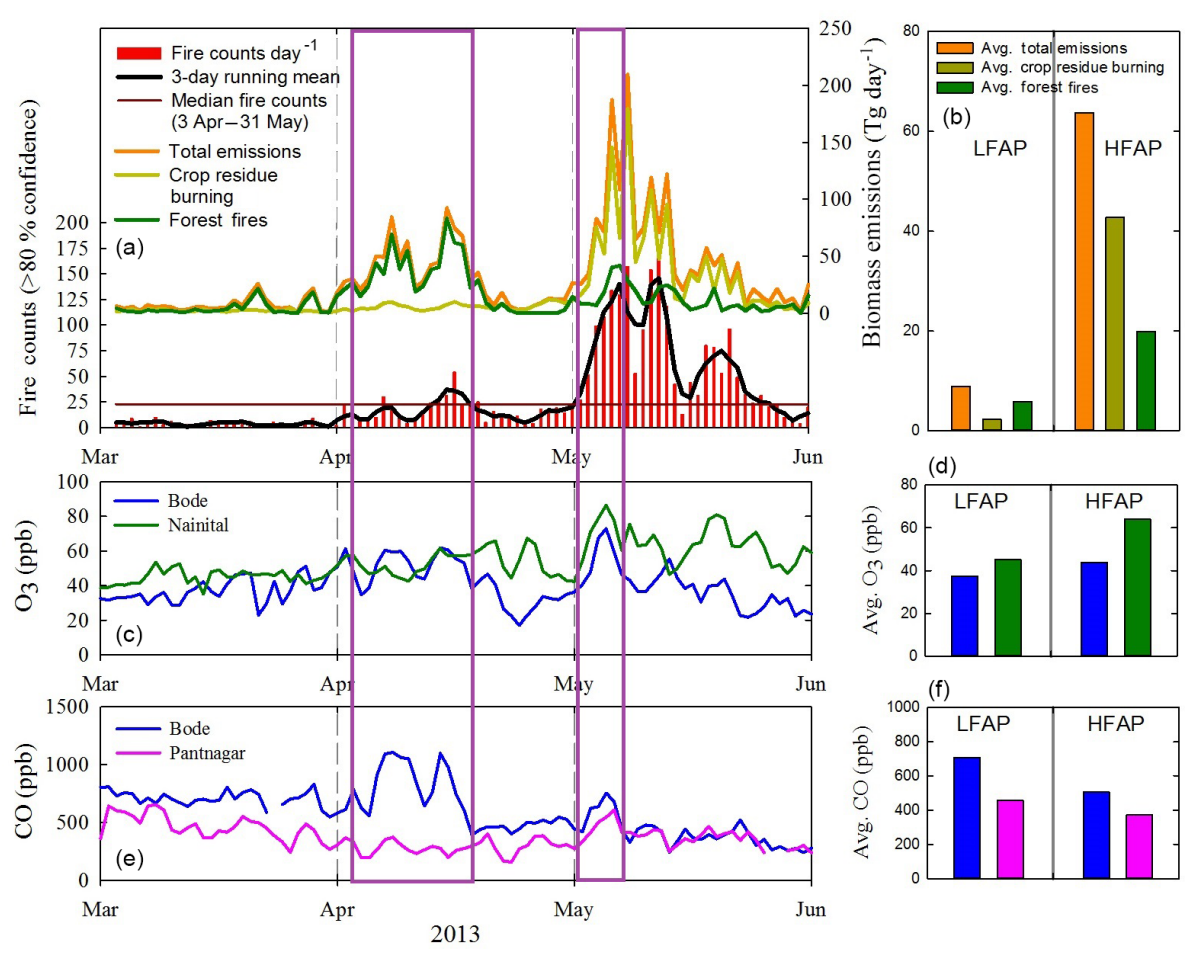

Figure 13. (a) Time series of MODIS daily fire counts (red bar), 3-day running mean (black lines) and median fire counts (brown line) for the fire period (3 April to 31 May 2013). Total biomass burning emissions (orange line), crop residue burning emissions (dark yellow line) and forest fire emissions (dark green) over a $1^{\circ} \times 1^{\circ}$ grid box around Bode $\left(27-28^{\circ} \mathrm{N}, 85-86^{\circ}\right.$ E) are also shown. (b) Average biomass burning emissions for two fire activity periods over the Bode region. (c, d) Time series of surface ozone mixing ratios at Bode and Nainital and average ozone mixing ratios during the two fire periods. (e, f) Time series of surface $\mathrm{CO}$ mixing ratios at Bode and Nainital and average $\mathrm{CO}$ mixing ratios during the two fire periods. The two fire events in April and May are also highlighted (in violet boxes).

these events show a large increase in MODIS fire counts in the Punjab region (blue box in top panel of Fig. 15) in the northwestern Indian subcontinent. During this period, the total increase in fire counts is $\sim 350 \%$ that of 25 30 April. The spatial distribution of AIRS-retrieved CO mixing ratios at $925 \mathrm{hPa}$ and $850 \mathrm{hPa}$ also indicates an overall increase in $\mathrm{CO}$ levels around the northern part of the Indian subcontinent. A similar increase is also observed in model (MOZART4/GEOS5) simulations in which a 2-fold increase in CO levels at $992 \mathrm{hPa}$ during this period is observed (Fig. S7). Further, OMI tropospheric column $\mathrm{NO}_{2}$ (30\% cloud screened) also showed a small enhancement during the same period (Fig. S7). The fire emissions associated with this period indicate that the majority of emissions are from crop residue burning, unlike the previous case in April. Late April-early May is the harvest period for crops in northern India, and widespread crop residue burning is common during this period. This leads to the release of massive amounts of pollutants over this region (Bhardwaj et al., 2016). The HYSPLIT backward air trajectories also indicate that air masses during the period were arriving from these source regions. During this period, nothing noticeable in wind speeds, directions, temperature solar radiation and rainfall is observed; thus we could conclude that this increase in surface mixing ratios of $\mathrm{O}_{3}$ and $\mathrm{CO}$ at these sites could be related to biomass burning in the northern Indian subcontinent. During this period, the influences are not only limited to the surface level but also to higher altitudes at which satelliteretrieved vertical profiles of $\mathrm{CO}$ show high levels during this period. Rupakheti et al. (2017) also reported a similar increase in the ambient concentrations of black carbon, particulate matter, $\mathrm{CO}$ and ozone at Lumbini (regional site of SusKat campaign) during these two episodes (7-9 April and 3-4 May). This site is located south of the Kathmandu Valley Himalayan foothills near the IGP. The notable changes in surface $\mathrm{O}_{3}$ and $\mathrm{CO}$ mixing ratios and GFED biomass burning emissions over the Kathmandu region are shown in Table 4.

Similar influences of widespread biomass burning have also been observed in the vertical distribution of ozone over the central Himalayas. Details of balloon-borne observations of ozone (Ojha et al., 2014) and meteorological parameters along with an intercomparison of two kinds of meteorological sensors (iMet and Vaisala) are given in Naja et al. (2016). The weekly balloon-borne ozone profiles from Nainital (on 9 May) also confirmed an enhancement in ozone $(\sim 16 \mathrm{ppb})$ in the lower troposphere $(2-4 \mathrm{~km})$ when compared with the ozone profile on 1 May (Fig. 16). The enhancement is about $14 \mathrm{ppbv}$ in the $4-6 \mathrm{~km}$ region. Such events are generally ob- 


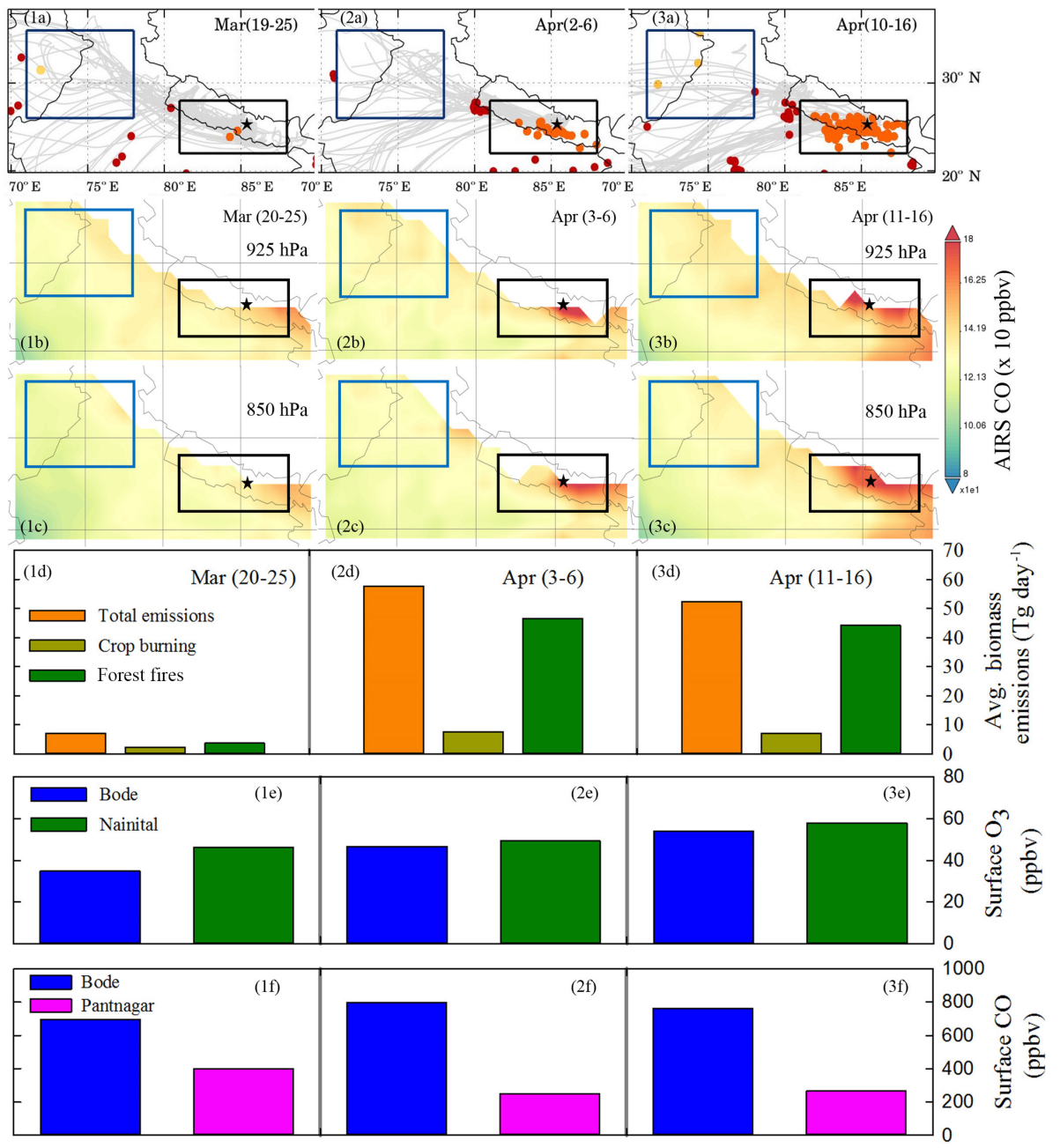

Figure 14. Top (1a-3a): spatial distribution of MODIS fire counts over the northern Indian subcontinent during three periods (left to right). The black boxes represent two fire hot spots (refer to Fig. S6) over the region with fire counts shown as different colors during the three periods. Center (1b-3c): spatial distribution of AIRS CO mixing ratio at $925 \mathrm{hPa}(\mathbf{1 b}-\mathbf{3 b})$ and $850 \mathrm{hPa}(\mathbf{1 c}-\mathbf{3 c})$ during three periods (left to right). Center (1d-3d): average biomass burning emissions over the Bode region $\left(27-8^{\circ} \mathrm{E}, 85-86^{\circ} \mathrm{E}\right)$ using the GFED v4.0 inventory during the three periods (left to right). Bottom (1e-3f): changes in average surface mixing ratios of $\mathrm{O}_{3}(\mathbf{1 e}-\mathbf{3 e})$ and $\mathrm{CO}$ (1f-3f) at different sites during the three periods (left to right).

served during the spring season, when the influence of regionally polluted air masses from the IGP could travel over long distances.

\subsection{Influences of stratosphere-troposphere exchange (STE) on surface ozone levels at Bode}

The tropopause folding events and influences of stratosphere-troposphere exchange (STE) over the Indian subcontinent and Tibetan Plateau are more frequent during winter and early spring (Cristofanelli et al., 2010; Chen et al., 2011; Phanikumar et al., 2017) and a few attempts in the past were made to understand the role of STE over the Indian subcontinent (Mandal et al., 1998; Ganguly and Tzanis, 2011). Here, to understand the role of STE in surface ozone levels in Kathmandu vertical distribution of Ertel potential vorticity (EPV) using MERRA v2.0 reanalysis, AIRS-retrieved ozone, $\mathrm{RH}$ and $\mathrm{CO}$ were observed during January-May 2013 (Fig. 17). The EPV distribution is represented by the potential vorticity unit (PVU) threshold $\quad\left(E P V>1.6 \mathrm{PVU}=1.6 \times 10^{-6} \mathrm{~K} \mathrm{~m}^{2} \mathrm{Kg}^{-1} \mathrm{~s}^{-1}\right)$ defined by Cristofanelli et al. (2006). Since the EPV near the extratropical tropopause is at about 2 PVU and EPV in the stratosphere is about 1-2 orders of magnitude higher, any values of EPV greater than 1.6 are suggested to be associated with the downward transport of ozone-rich air masses from above (Cristofanelli et al., 2006). Overall, EPV distribution suggests downward transport associated with STE is limited to the upper and middle parts of the troposphere (Fig. 17a). The ozone distribution also exhibits similar behavior for 

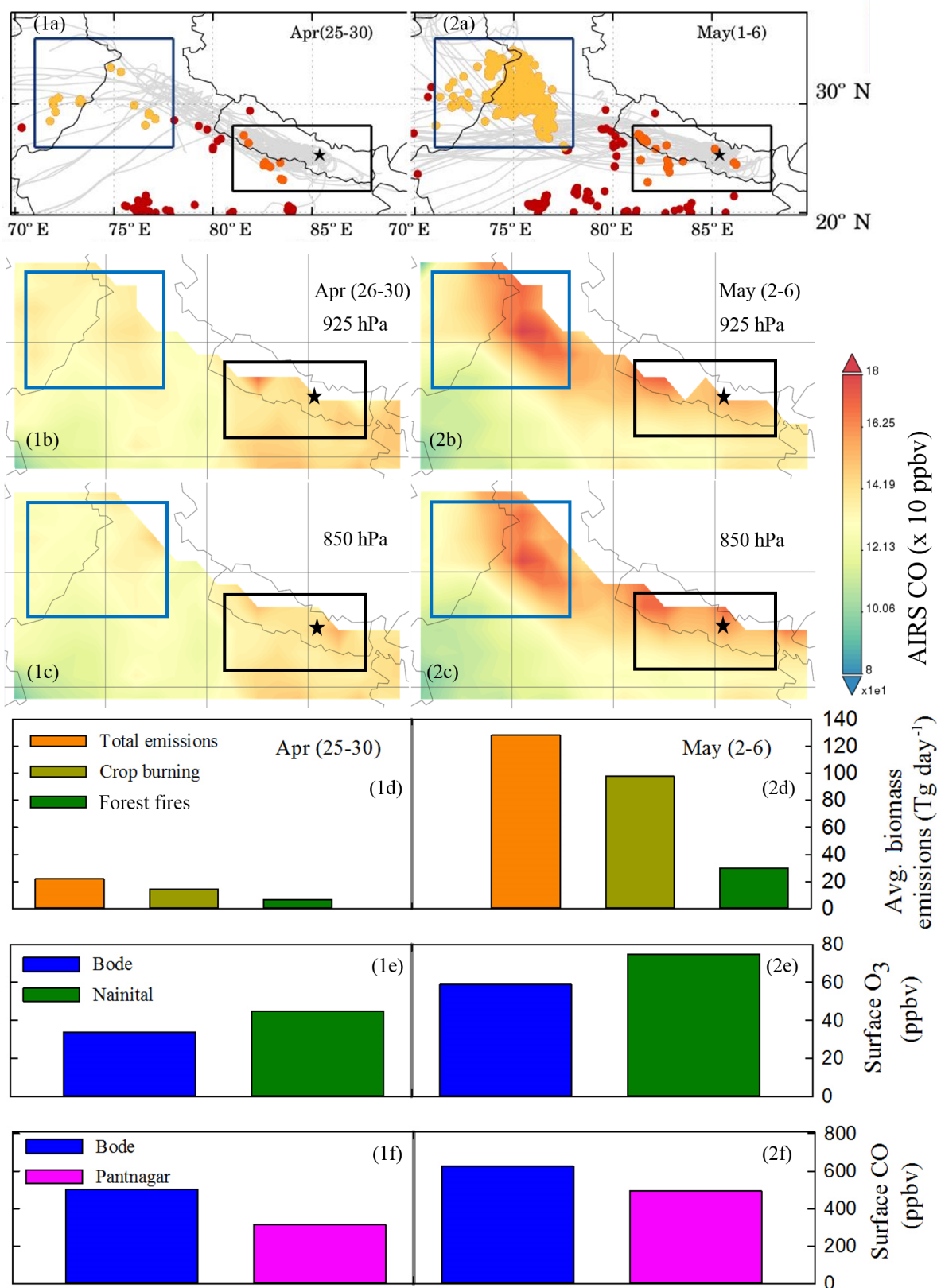

Figure 15. Top (1a-2b): spatial distribution of MODIS fire counts over the northern Indian subcontinent during the two periods (left to right). The black boxes represent two fire hot spots (refer to Fig. S1) over the region, with fire counts shown as different colors during different periods. Center (1b-2c): spatial distribution of AIRS CO mixing ratio at $925 \mathrm{hPa}(\mathbf{1 b}-\mathbf{2 b})$ and $850 \mathrm{hPa}(\mathbf{1 c}-\mathbf{2 c})$ during the two periods (left to right). Center (1d-2d): average biomass burning emissions over the Bode region $\left(27-8^{\circ} \mathrm{E}, 85-86^{\circ} \mathrm{E}\right)$ using the GFED v4.0 inventory during the two periods (left to right). Bottom (1e-2f): changes in average surface mixing ratios of $\mathrm{O}_{3}(\mathbf{1 e - 2 e )}$ and $\mathrm{CO}(\mathbf{1 f}-\mathbf{2 f})$ at different sites during the two periods (left to right).

which increases in ozone levels (downward transport) reaching the surface are negligible. However, a seasonal increase in ozone mixing ratios at the lower and middle troposphere can be observed during January to May. To investigate the role of STE during April and May, vertical profiles of EPV, $\mathrm{O}_{3}, \mathrm{CO}$ and $\mathrm{RH}$ were studied for these periods (Fig. 18). During the April event (Fig. 18a) EPV during 11-16 April was found to be increased compared to the previous period (March), but it was reduced during the 3-6 April period. During both the high fire periods, ozone and $\mathrm{CO}$ were higher during the event, which we propose is due to biomass burning since during STE reductions in CO are also observed. Therefore, the April event does not show any clear evidence of STE based on our analysis. Further, 


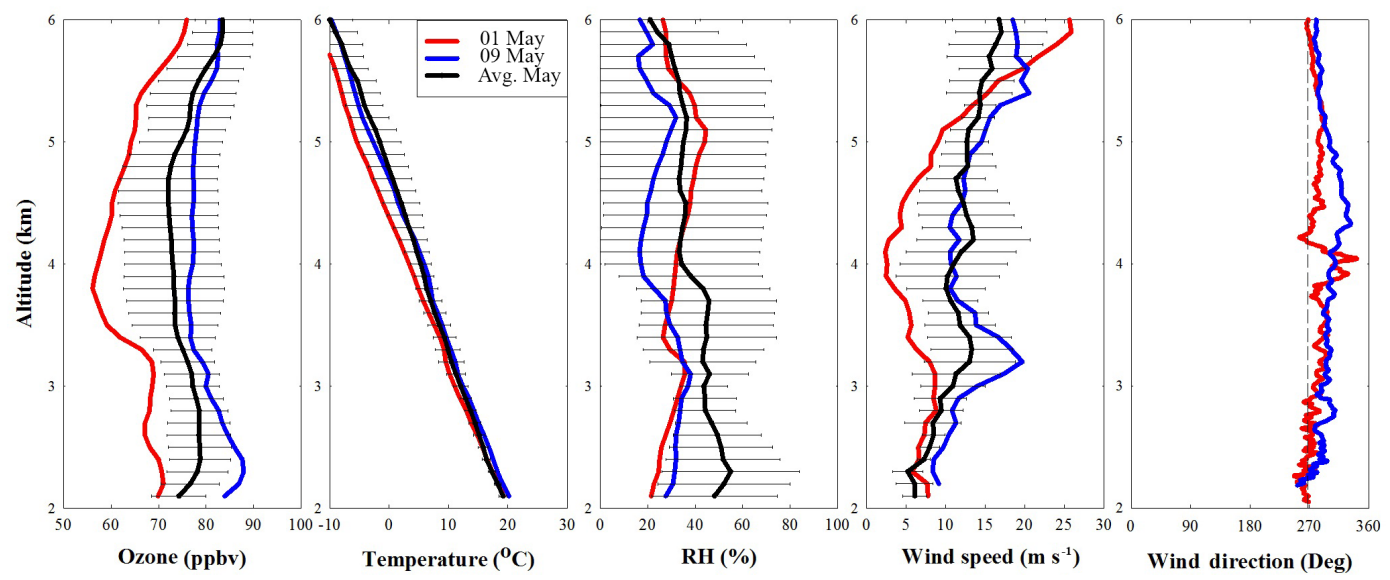

Figure 16. The vertical profiles of ozone, temperature, RH, wind speed and direction over the Nainital region on 1 (red) and 9 (blue) May 2013. The black lines show monthly average (May 2013) vertical profiles with bars representing $1 \sigma$ variations.

during May (Fig. 18b) an increase in EPV at higher altitudes and $\mathrm{O}_{3}$ at lower altitudes is observed, but again $\mathrm{CO}$ did not show any decrease during this period. Therefore, we conclude that during both of these high-pollution periods, no signs of downward transport were observed.

\section{Summary}

This study provides information about the regional distribution of $\mathrm{O}_{3}$ and $\mathrm{CO}$ during the SusKat-ABC field campaign (January-June 2013) by analyzing simultaneous surface measurements of ozone and CO from Bode in the Kathmandu Valley and from two Indian sites, Nainital and Pantnagar. Results from a few air samples and their analysis for eight $\left(\mathrm{C}_{2}-\mathrm{C}_{5}\right)$ light NMHCs are also presented. The diurnal variations show higher levels of ozone during the daytime and morning-evening peaks in $\mathrm{CO}$. This daytime buildup in ozone is consistent during all months, with a relatively smaller increment during the month of June due to prevailing cloudy or rainy conditions. Such a daytime increase in surface ozone is mainly due to photochemical production from precursor gases in the presence of sunlight. Very low nighttime levels of ozone were also observed during the winter season, which can be attributed to the titration of $\mathrm{O}_{3}$ by NO . The diurnal variations in $\mathrm{CO}$ showed two peaks during morning and evening hours, due mainly to rush hour traffic sources and cooking activities, and a similar distribution is also observed in Pantnagar. The evening peak was relatively less prominent at Bode due to fast westerly winds blowing across the valley during the afternoon that flush out $\mathrm{CO}$ in contrast to calm nighttime winds and a shallow nocturnal boundary layer, resulting in the highest levels during the morning. After reaching its maximum levels during the morning (up to $2300 \mathrm{ppbv}$ in winter months), the levels decrease as the day progresses. This decrease is attributed to the boundary layer evolution and strong winds blowing across the valley, which dilutes the $\mathrm{CO}$ levels.

The correlations between $\mathrm{O}_{3}$ and $\mathrm{CO}$ are found to be negative in the winter period $\left(r^{2}=0.82\right.$ in January and $r^{2}=0.71$ in February) and this negative correlation becomes weaker gradually, with the lowest value in May $\left(r^{2}=0.12\right)$. Hourly average $\mathrm{CO}$ levels also show a systematic decrease from the level of about $2100 \mathrm{ppbv}$ in January to about $600 \mathrm{ppbv}$ in June, whereas ozone shows the opposite tendency. A weaker negative correlation is observed during early morning (03:00-05:00 and 07:30-08:30 h) or nighttime hours (22:0023:00 h) while a slight positive correlation is seen around noon (13:00-15:00 h). The background $\mathrm{O}_{3}$ and $\mathrm{CO}$ levels at Bode are found to be about 14 and $325 \mathrm{ppbv}$, respectively. It is shown that $\mathrm{O}_{3}, \mathrm{CO}$ and light NMHC levels are higher at Bode than those at the IGP site (Pantnagar) and in the Himalayan foothills, particularly in winter. The rate of change of ozone during morning and evening hours is different at Bode, with a faster ozone increase rate during the day (about $\left.17 \mathrm{ppbv} \mathrm{h}^{-1}\right)$ but a slower ozone decrease rate $\left(5-6 \mathrm{ppbv} \mathrm{h}^{-1}\right)$ in the evening, suggesting the prevalence of a semi-urban kind of environment at Bode.

During the spring season, northern Indian biomass burning is found to affect the measurement sites in both India and Nepal. Two distinct events of biomass burning influence corresponding to the first half of April and May 2013 were studied. During both of these periods, an increase in $\mathrm{O}_{3}$ and $\mathrm{CO}$ is observed over Bode. A similar increase is also observed at Nainital during May, but not during April. During the first week of April, a sharp increase of $\sim 200 \mathrm{ppbv}$ in average CO mixing ratios is observed at Bode and an increase is also observed in ozone levels. The analysis of spatial distribution of MODIS-retrieved active fire locations indicated that the majority of fires took place in the nearby Nepalese regions that are upwind of Bode but downwind of Nainital. Analysis of biomass burning emission inventories indicated these emis- 
(a)
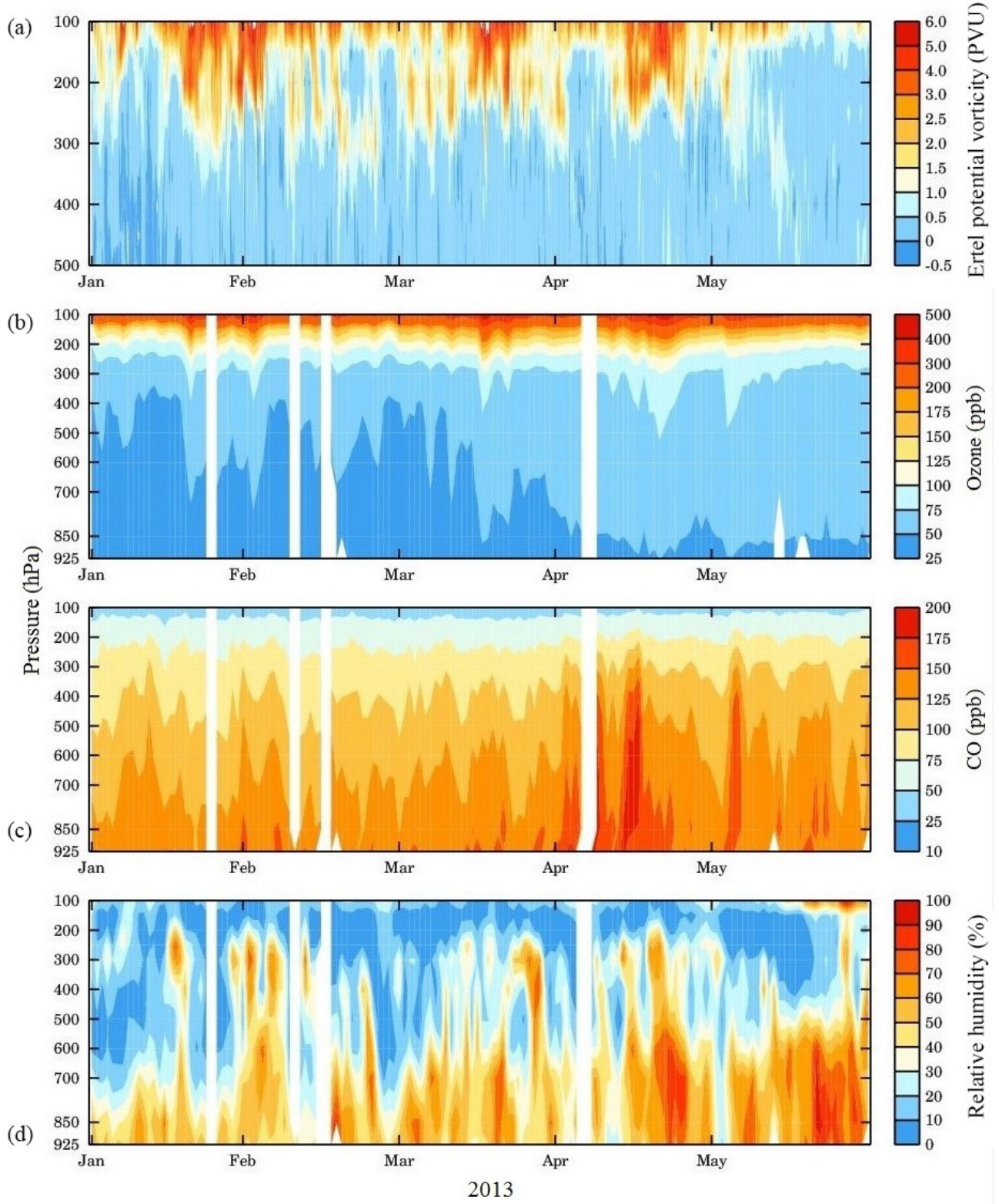

Figure 17. Vertical distribution of Ertel potential vorticity (EPV) calculated by MERRA v2 reanalysis (top), AIRS-retrieved ozone mixing ratios (center), CO mixing ratios (center) and relative humidity (RH) during January-May 2013.

sions originated primarily from burning of the forests. Satellite retrievals of lower-atmospheric $\mathrm{CO}$ mixing ratios also indicated an increase in $\mathrm{CO}$ levels during the event period near the Bode region but not near Pantnagar and Nainital. During the first week of May, simultaneous increases in $\mathrm{O}_{3}$ and $\mathrm{CO}$ levels were observed at Bode and Nainital. The MOZART simulations during that period also indicate about a 2-fold increase in near-surface $\mathrm{CO}$ levels. The MODIS-derived fire location showed $\mathrm{a} \sim 256 \%$ increment over the Punjab region in the IGP. Analysis of biomass burning emission inventories indicated that fires during May 2013 originated mainly from crop residue burning.
Analysis of backward air trajectories showed that the majority of the air masses passed over the fires in Punjab before arriving at Nainital, Pantnagar and Bode. Similar increases in near-surface distribution of satellite-retrieved $\mathrm{CO}$ mixing ratios around all the sites are also observed. The balloon-borne ozone profiles from Nainital also confirmed the significant enhancement in ozone ( $\sim 16 \mathrm{ppbv})$ in the lower troposphere between the balloon flights on 1 and 9 May 2013. Such events are mainly observed during the spring season when the influence of regionally polluted air masses from the IGP region are observed over measurement sites in the Himalayan region. This study provided the first regional picture of the 

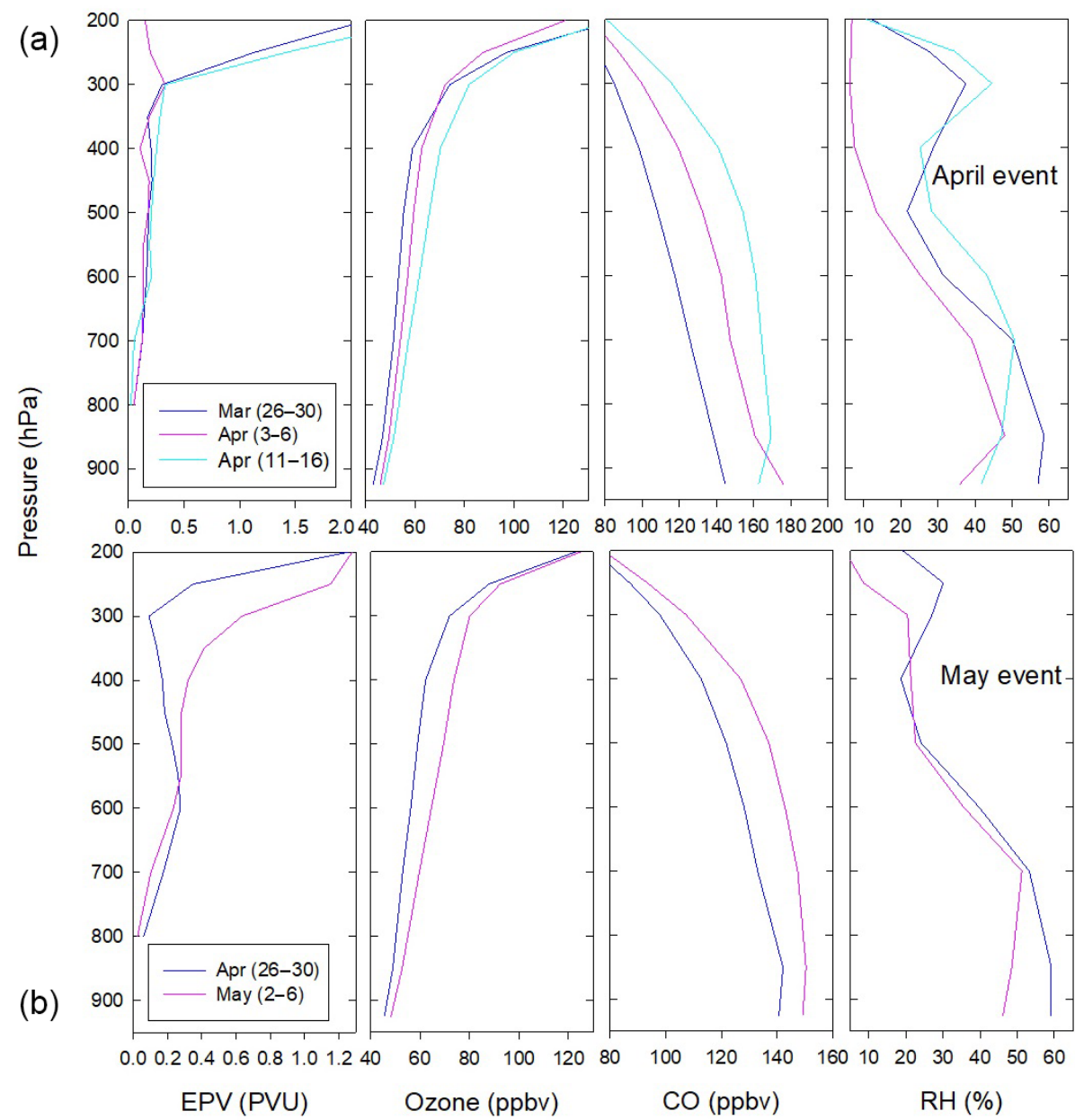

Figure 18. Vertical profiles of EPV, ozone, $\mathrm{CO}$ and $\mathrm{RH}$ during April (a) and May (b) biomass burning episodes.

air quality during the SusKat field campaign. Future studies should focus on long-term continuous and collocated $\mathrm{NO}_{x}$ and NMHC measurements to advance our understanding of atmospheric chemistry in this region. The SusKat dataset must also be used to identify and address the weaknesses of state-of-the-science air quality models and emission inventories, which together with observations will play an important role in developing effective mitigation strategies for this region and ultimately reducing the vulnerability of public health to frequently occurring air pollution episodes.

Data availability. Observational data collected for this study during the SusKat-ABC campaign can be obtained by contacting the corresponding author (manish@aries.res.in). These data will also be made public through a website maintained by the Institute for Advanced Sustainability Studies (IASS), Potsdam, Germany.

The Supplement related to this article is available online at https://doi.org/10.5194/acp-18-11949-2018supplement.
Author contributions. MR, MGL and AKP designed the SusKatABC campaign. MN and PB designed the measurement plan for this study. The paper was written by $\mathrm{PB}, \mathrm{MN}$ and RK. AL and AM provided model results and mixing-layer data, respectively. All coauthors made scientific improvements to the paper.

Competing interests. The authors declare that they have no conflict of interest.

Special issue statement. This article is part of the special issue "Atmospheric pollution in the Himalayan foothills: The SusKat-ABC international air pollution measurement campaign". It is not associated with a conference.

Acknowledgements. The SusKat field campaign was supported by IASS, Germany, and ICIMOD, Nepal. $\mathrm{O}_{3}, \mathrm{CO}$ and light NMHC observations are supported by the ATCTM project of ISRO Geosphere Biosphere Programme and ARIES, DST. The authors are thankful to Bhogendra Kathayat, Dipesh Rupakheti 
and Shyam Newar for their help in conducting observations at Bode. Shyam Lal is grateful to INSA, New Delhi, for the support for his position. The IASS is supported by the German Ministry of Education and Research (BMBF) and the Brandenburg State Ministry of Science, Research and Culture (MWFK). The National Center for Atmospheric Research is sponsored by the National Science Foundation. We are grateful to the teams of OMI, AIRS, MERRA-2, GFED, MOZART and HYSPLIT for making available the respective data. We are thankful to the three anonymous reviewers for their fruitful comments.

Edited by: Sachin S. Gunthe

Reviewed by: three anonymous referees

\section{References}

Beig, G., Gunthe, S., and Jadhav, D. B.: Simultaneous measurements of ozone and its precursors on a diurnal scale at a semi urban site in India, J. Atmos. Chem., 57, 239-253, https://doi.org/10.1007/s10874-007-9068-8, 2007.

Bhardwaj, P., Naja, M., Kumar, R., and Chandola, H. C.: Seasonal, interannual and long term variabilities in biomass burning activity over South Asia, Environ. Sci. Pollut. R., 23, 4397-4410, https://doi.org/10.1007/s11356-015-5629-6, 2016.

Bucsela, E. J., Krotkov, N. A., Celarier, E. A., Lamsal, L. N., Swartz, W. H., Bhartia, P. K., Boersma, K. F., Veefkind, J. P., Gleason, J. F., and Pickering, K. E.: A new stratospheric and tropospheric $\mathrm{NO}_{2}$ retrieval algorithm for nadir-viewing satellite instruments: applications to OMI, Atmos. Meas. Tech., 6, 26072626, https://doi.org/10.5194/amt-6-2607-2013, 2013.

Chen, X. L., Ma, Y. M., Kelder, H., Su, Z., and Yang, K.: On the behaviour of the tropopause folding events over the Tibetan Plateau, Atmos. Chem. Phys., 11, 5113-5122, https://doi.org/10.5194/acp-11-5113-2011, 2011.

Chou, M.-D. and Suarez, M. J.: An efficient thermal infrared radiation parametrization for use in general circulation models, NASA Tech. Memo., 104606, 85 pp., 1994.

Cristofanelli, P., Bonasoni, P., Tositti, L., Bonafe, U., Calzolari, F., Evangelisti, F., Sandrini, S., and Stohl, A.: A 6-year analysis of stratospheric intrusions and their influence on ozone at Mt. Cimone (2165 m above sea level), J. Geophys. Res., 111, D03306, https://doi.org/10.1029/2005JD006553, 2006.

Cristofanelli, P., Bracci, A., Sprenger, M., Marinoni, A., Bonafè, U., Calzolari, F., Duchi, R., Laj, P., Pichon, J. M., Roccato, F., Venzac, H., Vuillermoz, E., and Bonasoni, P.: Tropospheric ozone variations at the Nepal Climate ObservatoryPyramid (Himalayas, $5079 \mathrm{~m}$ a.s.1.) and influence of deep stratospheric intrusion events, Atmos. Chem. Phys., 10, 6537-6549, https://doi.org/10.5194/acp-10-6537-2010, 2010.

de Foy, B., Varela, J. R., Molina, L. T., and Molina, M. J.: Rapid ventilation of the Mexico City basin and regional fate of the urban plume, Atmos. Chem. Phys., 6, 2321-2335, https://doi.org/10.5194/acp-6-2321-2006, 2006.

Department of Transport Management (DOTM): available at: http: //www.dotm.gov.np/en (last access: 31 July 2018), 2015.

Draxler, R. R. and Hess, G. D.: An overview of the HYSPLIT_4 modelling system for trajectories, dispersion, and deposition, Aust. Meteorol. Mag., 47, 295-308, 1998.
Gaur, A., Tripathi, S. N., Kanawade, V. P., Tare, V., and Shukla, S. P.: Four-year measurements of trace gases $\left(\mathrm{SO}_{2}, \mathrm{NO}_{x}, \mathrm{CO}\right.$, and $\mathrm{O}_{3}$ ) at an urban location, Kanpur, in Northern India, J. Atmos. Chem., 71, 283-301, https://doi.org/10.1007/s10874-014-92958, 2014.

Ganguly N. D. and Tzanis, C.: Study of Stratosphere-Troposphere exchange events of ozone in India and Greece using ozonesonde ascents, Meteorol. Appl., 18, 467-474, 2011.

Gelaro, R., McCarty, W., Suárez, M. J., Todling R., Molod, A., Takacs, L., Randles C. A., Darmenov, A., Bosilovich, M. G., Reichle, R., Wargan, K., Coy, L., Cullather, R., Draper, C., Akella, S., Buchard, V., Conaty, A., da Silva, A. M., Gu, W., Kim, G. K., Koster, R., Lucchesi, R., Merkova, D., Nielsen, J. E., Partyka, G., Pawson, S., Putman, W., Rienecker, M., Schubert, S. D., Sienkiewicz, M., and Zhao, B.: The modern-era retrospective analysis for research and applications, version 2 (MERRA-2), J. Climate, 30, 5419-5454, https://doi.org/10.1175/JCLI-D-160758.1, 2017.

Giglio, L.: MODIS Collection 5 Active Fire Product User's Guide Version-2.4, available at: http://www.fao.org/fileadmin/ templates/gfims/docs/MODIS_Fire_Users_Guide_2.4.pdf (last access: 10 March 2017), 2010.

Giglio, L., Descloitres, J., Justice, C. O., and Kaufman, Y. J.: An enhanced contextual fire detection algorithm for MODIS, Remote Sens. Environ., 87,, 273-282, https://doi.org/10.1016/S00344257(03)00184-6, 2003.

Grell, G. and Dévényi, D.: A generalized approach to parameterizing convection combining ensemble and data assimilation techniques, Geophys. Res. Lett., 29, 38-1-38-4, https://doi.org/10.1029/2002GL015311, 2002.

Guenther, A., Karl, T., Harley, P., Wiedinmyer, C., Palmer, P. I., and Geron, C.: Estimates of global terrestrial isoprene emissions using MEGAN (Model of Emissions of Gases and Aerosols from Nature), Atmos. Chem. Phys., 6, 3181-3210, https://doi.org/10.5194/acp-6-3181-2006, 2006.

Hong, S.-Y., Noh, Y., and Dudhia, J.: A New Vertical Diffusion Package with an Explicit Treatment of Entrainment Processes, Mon. Weather Rev., 134, 2318-2341, https://doi.org/10.1175/MWR3199.1, 2006.

Iacono, M. J., Delamere, J. S., Mlawer, E. J., Shephard, M. W., Clough, S. A., and Collins, W. D.: Radiative forcing by long-lived greenhouse gases: Calculations with the AER radiative transfer models, J. Geophys. Res., 113, D13103, https://doi.org/10.1029/2008JD009944, 2008.

Jiménez, P. A., Dudhia, J., González-Rouco, J. F., Navarro, J., Montávez, J. P., and García-Bustamante, E.: A Revised Scheme for the WRF Surface Layer Formulation, Mon. Weather Rev., 140, 898-918, https://doi.org/10.1175/MWR-D-11-00056.1, 2012.

Justice, C., Giglio, L., Boschetti, L., Roy, D., Csiszar, I., Morisette, J., and Kaufman Y.: Algorithm Technical Background Document, MODIS FIRE PRODUCTS, (Version 2.3, 1 October 2006), 2006.

Kajii, Y., Someno, K., Tanimoto, H., Hirokawa, J., Akimoto, H., Katsuno, T., and Kawara, J.: Evidence for the seasonal variation of photo-chemical activity of tropospheric ozone: Continuous observation of ozone and CO at Happo, Japan, Geophys. Res. Lett., 25, 3505-3508, 1998. 
Kleinman, L.: Ozone formation at a rural site in the southern United State, J. Geophys. Res., 99, 3469-3482, https://doi.org/10.1029/93JD02991, 1994.

Kumar, R., Naja, M., Venkataramani, S., and Wild, O.: Variations in surface ozone at Nainital, a high altitude site in the Central Himalayas, J. Geophys. Res., 115, D16302, https://doi.org/10.1029/2009JD013715, 2010.

Kumar, R., Naja, M., Satheesh, S. K., Ojha, N., Joshi, H., Sarangi, T., Pant, P., Dumka, U. C., Hegde, P., and Venkataramani, S.: Influences of the springtime northern Indian biomass burning over the central Himalayas, J. Geophys. Res., 116, D19302, https://doi.org/10.1029/2010JD015509, 2011.

Kumar, R., Naja, M., Pfister, G. G., Barth, M. C., and Brasseur, G. P.: Source attribution of carbon monoxide in India and surrounding regions during wintertime, J. Geophys. Res.-Atmos., 118, 1981-1995, https://doi.org/10.1002/jgrd.50134, 2013.

Kumar, V., Sarkar, C., and Sinha, V.: Influence of post-harvest crop residue fires on surface ozone mixing ratios in the NW IGP analyzed using two years of continuous in-situ trace gas measurements, J. Geophys. Res.-Atmos., 121, 3619-3633, https://doi.org/10.1002/2015JD024308, 2016.

Lal, S., Naja, M., and Subbaraya, B. H.: Seasonal variations in surface ozone and its precursors over an urban site in India, Atmos. Environ., 34, 2713-2724, https://doi.org/10.1016/S13522310(99)00510-5, 2000.

Lal, S., Sahu, L. K., Gupta, S., Srivastava, S., Modh, K. S., Venkataramani, S., and Rajesh T. A.: Emission characteristics of ozone related trace gases at a semi-urban site in Indo-Ganetic plain using inter-correlations, J. Atmos. Chem., 60, 189-204, https://doi.org/10.1007/s10874-008-9115-0, 2008.

Lal, S., Venkataramani, S., Srivastava, S., Gupta, S., Mallik, C., Naja, M., Sarangi, T., Acharya, Y. B., and Liu, X.: Transport effects on the vertical distribution of tropospheric ozone over the tropical marine regions surrounding India, J. Geophys. Res.Atmos., 118, 1513-1524, https://doi.org/10.1002/jgrd.50180, 2013.

Li, G., Zhang, R., Fan, J., and Tie, X.: Impacts of black carbon aerosol on photolysis and ozone, J. Geophys. Res., 110, D23206, https://doi.org/10.1029/2005JD005898, 2005.

Lin, Y.-L., Farley, R. D., and Orville, H. D.: Bulk Parameterization of the Snow Field in a Cloud Model, J. Clim. Appl. Meteorol., 22, 1065-1092, https://doi.org/10.1175/15200450(1983)022<1065:BPOTSF>2.0.CO;2, 1983.

Mahata, K. S., Panday, A. K., Rupakheti, M., Singh, A., Naja, M., and Lawrence, M. G.: Seasonal and diurnal variations in methane and carbon dioxide in the Kathmandu Valley in the foothills of the central Himalayas, Atmos. Chem. Phys., 17, 12573-12596, https://doi.org/10.5194/acp-17-12573-2017, 2017.

Mallik, C., Ghosh, D., Ghosh, D., Sarkar, U., Lal, S., and Venkataramani, S.: Variability of SO2, CO, and light hydrocarbons over a megacity in Eastern India: effects of emissions and transport, Environ. Sci. Pollut. R., 21, 8692, https://doi.org/10.1007/s11356014-2795-x, 2014.

Mandal, T. K., Cho, J. Y. N., Rao, P. B., Jain, A. R., Peshin, S. K., Srivastava, S. K., Bohra, A. K., and Mitra, A. P.: Stratospheretroposphere ozone exchange observed with the Indian MST radar and a simultaneous balloon-borne ozonesonde, Radio Sci., 33, 861-893, https://doi.org/10.1029/97RS03553, 1998.
Martilli, A., Neftel, A., Favaro, G., Kirchner, F., Sillman, S., and Clappier, A.: Simulation of the ozone formation in the northern part of the Po Valley, J. Geophys. Res., 107, 8195, https://doi.org/10.1029/2001JD000534, 2002.

Molina, L. T., Kolb, C. E., de Foy, B., Lamb, B. K., Brune, W. H., Jimenez, J. L., Ramos-Villegas, R., Sarmiento, J., ParamoFigueroa, V. H., Cardenas, B., Gutierrez-Avedoy, V., and Molina, M. J.: Air quality in North America's most populous city overview of the MCMA-2003 campaign, Atmos. Chem. Phys., 7, 2447-2473, https://doi.org/10.5194/acp-7-2447-2007, 2007.

Mues, A., Rupakheti, M., Münkel, C., Lauer, A., Bozem, H., Hoor, P., Butler, T., and Lawrence, M. G.: Investigation of the mixing layer height derived from ceilometer measurements in the Kathmandu Valley and implications for local air quality, Atmos. Chem. Phys., 17, 8157-8176, https://doi.org/10.5194/acp17-8157-2017, 2017.

Mues, A., Lauer, A., Lupascu, A., Rupakheti, M., Kuik, F., and Lawrence, M. G.: WRF and WRF-Chem v3.5.1 simulations of meteorology and black carbon concentrations in the Kathmandu Valley, Geosci. Model Dev., 11, 2067-2091, https://doi.org/10.5194/gmd-11-2067-2018, 2018.

Naja, M. and Lal, S.: Surface ozone and precursor gases at Gadanki $\left(13.5^{\circ} \mathrm{N}, 79.2^{\circ} \mathrm{E}\right)$, tropical rural site in India, J. Geophys. Res., 107, 4197, https://doi.org/10.1029/2001JD000357, 2002.

Naja, M., Lal, S., and Chand, D.: Diurnal and seasonal variabilities in surface ozone at a high altitude site $\mathrm{Mt} \mathrm{Abu}\left(24.6^{\circ} \mathrm{N}, 72.7^{\circ} \mathrm{E}\right.$, $1680 \mathrm{~m}$ asl) in India, Atmos. Environ., 37, 4205-4215, 2003.

Naja, M., Bhardwaj, P., Singh, N., Kumar, P., Kumar, R., Ojha, N., Sagar, R., Satheesh, S. K., Moorthy, K. K., and Kotamarthi, V. R.: High-frequency vertical profiling of meteorological parameters using AMF1 facility during RAWEX-GVAX at ARIES, Nainital, Curr. Sci., 111, 132-140, 2016.

Ojha, N., Naja, M., Singh, K. P., Sarangi, T., Kumar, R., Lal, S., Lawrence, M. G., Butler, T. M., and Chandola, H. C.: Variabilities in ozone at a semi-urban site in the Indo-Gangetic Plain region: Association with the meteorology and regional processes, J. Geophys. Res., 117, D20301, https://doi.org/10.1029/2012JD017716, 2012.

Ojha, N., Naja, M., Sarangi, T., Kumar, R., Bhardwaj, P., Lal, S., Venkataramani, S., Sagar, R., Kumar, A., and Chandola, H. C.: On the processes influencing the vertical distribution of ozone over the central Himalayas: Analysis of yearlong ozonesonde observations, Atmos. Environ., 88, 201-211, https://doi.org/10.1016/j.atmosenv.2014.01.031, 2014.

Panday, A. K. and Prinn, R. G.: The diurnal cycle of air pollution in the Kathmandu Valley, Nepal: Observations, J. Geophys. Res., 114, D09305, https://doi.org/10.1029/2008JD009777, 2009.

Phanikumar, D. V., Kumar, K. N., Bhattacharjee, S., Naja, M., Girach, I. A., Nair, P. R., and Kumari, S.: Unusual enhancement in tropospheric and surface ozone due to orography induced gravity waves, Remote Sens. Environ., 199, 256-264, https://doi.org/10.1016/j.rse.2017.07.011, 2017.

Pochanart, P., Hirokawa, J., Kajii, Y., Akimoto, H., and Nakao, M.: The influence of regional scale anthropogenic activity in northeast Asia on seasonal variations of surface ozone and carbon monoxide observed at Oki, Japan, J. Geophys. Res., 104, 36213631, 1999. 
Pradhan, B. B., Dangol, P. M., Bhaunju, R. M., and Pradhan, S.: Rapid urban assessment of air quality for Kathmandu, Nepal: Summary, Kathmandu, ICIMOD, 2012.

Pudasainee, D., Sapkota, B., Shrestha, M. L., Kaga, A., Kondo, A., and Inoue, Y.: Ground level ozone concentrations and its association with $\mathrm{NO}_{x}$ and meteorological parameters in Kathmandu Valley, Nepal, Atmos. Environ., 40, 8081-8087, https://doi.org/10.1016/j.atmosenv.2006.07.011, 2006.

Pun, B. K., Seigneur C., and White W.: Day-of-Week Behavior of tropospheric Ozone in Three U.S. Cities, J. Air Waste Manage., 53, 789-801, https://doi.org/10.1080/10473289.2003.10466231, 2003.

Putero, D., Landi, T. C., Cristofanelli, P., Marinoni, A., Laj, P., Duchi, R., Calzolari, F., Verza, G. P., and Bonasoni, P.: Influence of open vegetation fires on black carbon and ozone variability in the southern Himalayas (NCO-P, 5079 m a.s.l.), Environ. Pollut., 184, 597-604, 2014.

Putero, D., Cristofanelli, P., Marinoni, A., Adhikary, B., Duchi, R., Shrestha, S. D., Verza, G. P., Landi, T. C., Calzolari, F., Busetto, M., Agrillo, G., Biancofiore, F., Di Carlo, P., Panday, A. K., Rupakheti, M., and Bonasoni, P.: Seasonal variation of ozone and black carbon observed at Paknajol, an urban site in the Kathmandu Valley, Nepal, Atmos. Chem. Phys., 15, 13957-13971, https://doi.org/10.5194/acp-15-13957-2015, 2015.

Rappenglück, B., Schmitz, R., Bauerfeind, M., Cereceda-Balic, F., von Baer, D., Jorquera, H., Silva, Y., and Oyola, P.: An urban photochemistry study in Santiago de Chile, Atmos. Environ., 39, 2913-2931, https://doi.org/10.1016/j.atmosenv.2004.12.049, 2005.

Rupakheti, D., Adhikary, B., Praveen, P. S., Rupakheti, M., Kang, S., Mahata, K. S., Naja, M., Zhang, Q., Panday, A. K., and Lawrence, M. G.: Pre-monsoon air quality over Lumbini, a world heritage site along the Himalayan foothills, Atmos. Chem. Phys., 17, 11041-11063, https://doi.org/10.5194/acp-17-110412017, 2017.

Rupakheti, M., Panday, A. K., Lawrence, M. G., Kim, S., Sinha, V., Kang, S., Naja, M., Park, J., Hoor, P., Holben, B., Bonasoni, P., Sharma, R., Gustafsson, Ö., Mahata, K., Bhardwaj, P., Sarkar, C., Rupakheti, D., Regmi, R., and Pandit, A., Atmospheric pollution in the Himalayan foothills: Overview of the SusKat-ABC field campaign in Nepal, Atmos. Chem. Phys., in preparation, 2018.

Sarangi, T., Naja, M., Ojha, N., Kumar, R., Lal, S., Venkataramani, S., Kumar, A., Sagar, R., and Chandola, H. C.: First simultaneous measurements of ozone, CO, and NOy at a high-altitude regional representative site in the central Himalayas, J. Geophys. Res.-Atmos., 119, 1592-1611, https://doi.org/10.1002/2013JD020631, 2014.

Sarangi, T., Naja, M., Lal, S., Venkataramani, S., Bhardwaj, P., Ojha, N., Kumar, R., and Chandola, H. C.: First observations of light non-methane hydrocarbons $\left(\mathrm{C}_{2}-\mathrm{C}_{5}\right)$ over a high altitude site in the central Himalayas, Atmos. Environ., 125, 450-460, https://doi.org/10.1016/j.atmosenv.2015.10.024, 2016.
Sarkar, C., Sinha, V., Kumar, V., Rupakheti, M., Panday, A., Mahata, K. S., Rupakheti, D., Kathayat, B., and Lawrence, M. G.: Overview of VOC emissions and chemistry from PTR-TOFMS measurements during the SusKat-ABC campaign: high acetaldehyde, isoprene and isocyanic acid in wintertime air of the Kathmandu Valley, Atmos. Chem. Phys., 16, 3979-4003, https://doi.org/10.5194/acp-16-3979-2016, 2016.

Schmitz, R.: Modelling of air pollution dispersion in Santiago de Chile, Atmos. Environ., 39, 2035-2047, https://doi.org/10.1016/j.atmosenv.2004.12.033, 2005.

Sinha, V., Kumar, V., and Sarkar, C.: Chemical composition of premonsoon air in the Indo-Gangetic Plain measured using a new air quality facility and PTR-MS: high surface ozone and strong influence of biomass burning, Atmos. Chem. Phys., 14, 59215941, https://doi.org/10.5194/acp-14-5921-2014, 2014.

Susskind, J., Barnet, C. D., Blaisdell, J. M., Center, G. S. F., and Greenbelt, M. D.: Retrieval of atmospheric and surface parameters from AIRS/AMSU/HSB data in the presence of clouds, IEEE T. Geosci. Remote, 41, 390-409, https://doi.org/10.1109/TGRS.2002.808236, 2003.

Susskind, J., Barnet, C. D., Blaisdell, J. M., Iredell, L., Keita, F., Kouvaris, L., Molnar, G., and Chahine, M. T.: Accuracy of geophysical parameters derived from Atmospheric Infrared Sounder/Advanced Microwave Sounding Unit as a function of fractional cloud cover, J. Geophys. Res., 111, D09S17, https://doi.org/10.1029/2005JD006272, 2006.

Tie, X., Madronich, S., Walters, S., Zhang, R., Rasch, P., and Collins, W.: Effect of clouds on photolysis and oxidants in the troposphere, J. Geophys. Res., 108, 4642, https://doi.org/10.1029/2003JD003659, 2003.

Tsutsumi, Y. and Matsueda, H.: Relationship of ozone and CO at the summit of Mt. Fuji $\left(35.35^{\circ} \mathrm{N}, 138.73^{\circ} \mathrm{E}, 3776 \mathrm{~m}\right.$ above sea level) in summer 1997, Atmos. Environ., 34, 553-561, https://doi.org/10.1016/S1352-2310(99)00238-1, 2000.

Wesely, M. L.: Parameterization of surface resistance to gaseous dry deposition in regional-scale numerical models, Atmos. Environ., 23, 1293-1304, 1989

Wiedinmyer, C., Akagi, S. K., Yokelson, R. J., Emmons, L. K., AlSaadi, J. A., Orlando, J. J., and Soja, A. J.: The Fire INventory from NCAR (FINN): a high resolution global model to estimate the emissions from open burning, Geosci. Model Dev., 4, 625641, https://doi.org/10.5194/gmd-4-625-2011, 2011.

Yu, Y., Galle, B., Panday, A., Hodson, E., Prinn, R., and Wang, S.: Observations of high rates of $\mathrm{NO}_{2}-\mathrm{HONO}$ conversion in the nocturnal atmospheric boundary layer in Kathmandu, Nepal, Atmos. Chem. Phys., 9, 6401-6415, https://doi.org/10.5194/acp-9-64012009, 2009. 